Research Article/Araştırma Makalesi

\title{
Evaluation of Students' Learning the Subject of "Limit-Continuity" in a Computer-Aided Environment According to the SOLO Taxonomy: Action Research
}

\author{
Elif ERTEM AKBAŞ * 1 (D) Adnan BAKİ 2 (D) \\ ${ }^{1}$ Van Yüzüncü Yıl University, Faculty of Education, Van, Turkey, eertema@gmail.com \\ ${ }^{2}$ Trabzon University, Faculty of Education, Trabzon, Turkey, adnanbaki@gmail.com \\ * Corresponding Author: eertema@gmail.com
}

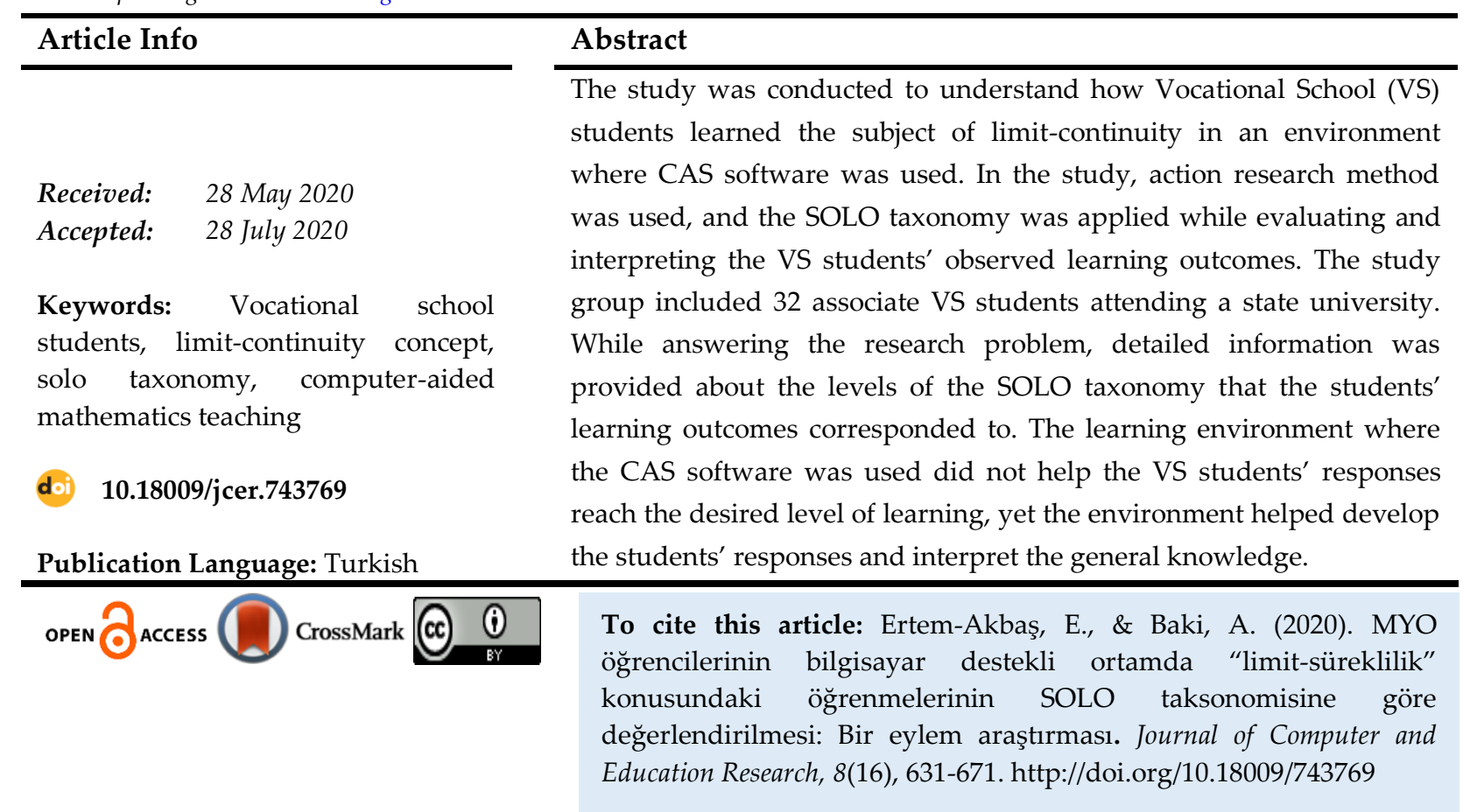

\section{MYO Öğrencilerinin Bilgisayar Destekli Ortamda "Limit-Süreklilik" Konusundaki Öğrenmelerinin SOLO Taksonomisine Göre Değerlendirilmesi: Bir Eylem Araştırması}

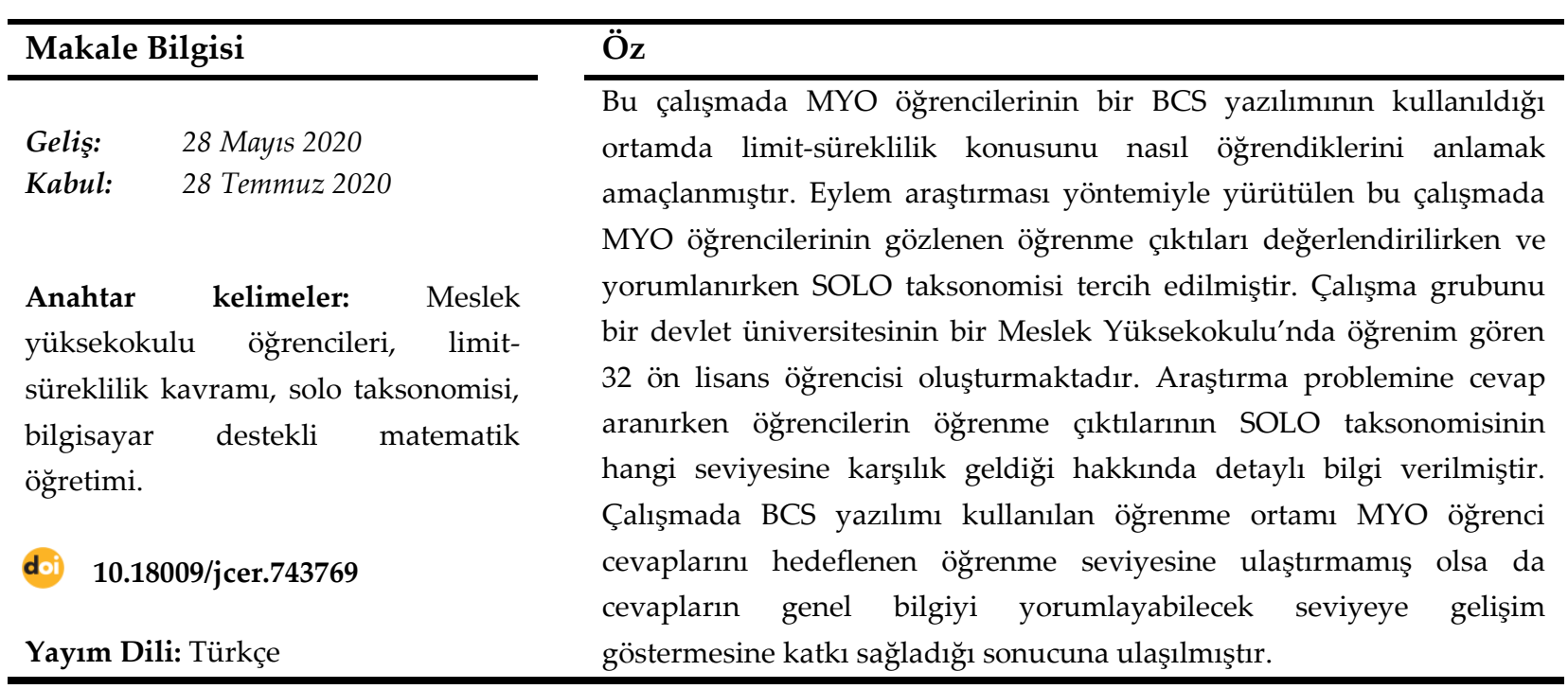




\section{Summary}

\section{Evaluation of Students' Learning the Subject of "Limit-Continuity" in a Computer-Aided Environment According to the SOLO Taxonomy: Action Research}

\section{Introduction}

In our country, considering the fact that $60 \%$ of high-school graduates students showing success in the university placement exam continue their undergraduate education, it is important to look into the teaching of the concepts of limit-continuity found in the content of general mathematics course given at universities and especially at vocational schools. The fact that Vocational School (VS) students have more problems in learning the concepts of limit and continuity when compared to undergraduate students learning general or basic mathematics will bear certain difficulties in the transition process. In fact, when computer algebra systems (CAS), which can apply mathematical procedures and algorithms more rapidly and reliability than the best mathematicians are used in line with appropriate subjects and purposes, these procedures and algorithms can be understood more easily (Çelik, 2007; Kokol-Voljc, 2000). Use of CAS in class environments allows students to represent various situations, to use symbols and to benefit from and interpret graphicalnumerical representations besides symbolic representations.

The present study focused on the subject of limit-continuity, whose dimension of conceptual understanding is thought to be ignored due to the anxiety of preparing for the university placement exam. Especially VS students, who lack basic mathematics knowledge, should learn the subject of limit-continuity, the keystone of general mathematics. In order to allow VS students to learn these subjects effectively and permanently, a learning environment formed by using the Derive software of CAS was designed. In the study, for indepth evaluation of the students' learning the subject of limit-continuity in this environment, the SOLO taxonomy, which was developed by Biggs and Collis (1991) and defined as general information model, was used. Each student's processes of thinking and interpreting the concepts of limit-continuity could be formed by defining certain levels of understanding. Therefore, VS students' learning the subject of limit-continuity in the computer-aided learning environment at universities could be evaluated in accordance with the SOLO 
taxonomy. In this way, it could be possible to examine whether learning environments to be formed with the help of technological developments will contribute to VS students' conceptual understanding. In this respect, the present study is thought to contribute to the related literature in terms of evaluation of VS students' learning the subject of limitcontinuity in a computer-aided environment.

\section{Method}

In the study, which was carried out using the action research design, the SOLO taxonomy was used to evaluate and interpret the observed learning outcomes of VS students. The study group included 32 associate students from a Vocational School of a state university. The participants were determined using the convenience sampling method. The data sources in the study included worksheets, the screen prints of the students' computers, observations, researcher's notes, dialogues and audio records. While finding answers to the research problem, detailed information about which level of the SOLO taxonomy the students' learning outcomes corresponded to was provided.

\section{Results}

The findings obtained in the study are presented under three headings within the framework of the sub-problems in the study. Under these sub-headings, the descriptive analysis results regarding the students' responses and the levels of the SOLO taxonomy which their responses belonged to have been presented by proving the underlying reasons.

When the tables, graphs and dialogues given to summarize the groups in general were examined in processes, it was seen that the students who tended to use pen-and-pencil before starting to use the software gave responses focusing on one aspect of the questions; that their responses developed in line with the use of the software, and that their responses included meaningful independent or interrelated pieces of independent knowledge. In the next academic term, the students tended to use the software to solve the questions in the worksheets. The fact that the students who had difficulty examining the function graph, limit and continuity without the Derive software tended to use the software showed an increase in the tendency towards technology in the learning process. In addition, the fact that the procedures were made more meaningful with the help of the software showed that CAS contributed to the students' abstract thinking in the learning process. 


\section{Discussion and Conclusion}

In general, in the environment where the CAS software was used, the VS students' learning outcomes related to the subject of limit-continuity were below the IYY (Relational) level according to SOLO taxonomy. Moreover, with the use of the CAS software, the quality and structure of the VS students' learning outcomes at YÖ (Prestructural) and TY (Unistructural) levels developed towards the ÇY (Multistructural) and IY levels except for the SY (Extended abstract) level. When the data obtained in relation to finding limit in the case of ambiguity function, it was seen that the students' responses generally were at the levels of TY and ÇY according to the SOLO taxonomy. Considering the fact that in order to achieve learning how to find the limit value in ambiguity function cases, the VS students' responses should have been at the IYY level, which refers to understanding interrelated concepts, it could obviously be stated that the expected learning did not occur. When examined with respect to the distribution of the question groups, the questions that the VS students had the biggest difficulty were found to belong to this group.

In relation to finding the continuous intervals by examining the function graph, the VS students' responses were at ÇY level increasing to İY level according to the SOLO taxonomy. This situation shows that VS students who did not have any problems in drawing graph with the Derive software achieve the expected learning in relation to finding the continuous intervals via the examination of the graph of the functions and examining the limit at the point given in the graph. The fact that the students became closer to the expected learning could be considered to be an indicator of the development of their use of the visual representations. In relation to establishing a relationship between limit-continuity, the VS students' responses generally increased to the levels of ÇY and ÇY+ according to the SOLO taxonomy. This situation shows that though the expected learning regarding associating the subject of limit-continuity was not achieved, the students' responses turned into statements trying to interpret the general knowledge. It was revealed that the VS students, who tended to draw a graph for function and who failed to avoid the memorized pieces of knowledge about limit-continuity were under the influence of their previous practices while responding to the questions in this group and that they had certain misconceptions. This result might have been due to the fact that the functions in the question groups were undefined or unclear in terms of the points to be examined and that the VS students were already accustomed to rule-based and memorization-based learning. 


\section{Giriş}

Eğitim sektöründe bilgisayar kullanımındaki artış matematik eğitiminde yeni beklentiler ortaya çıkarmıştır. Bu beklentilere göre yarının sınıfları bugünün sınıflarından farklı olacak, öğrenciler teknoloji ile matematiği kendi başlarına keşfedebilecekler ve kâğıtkalem uygulamaları ikinci planda kalacaktır (Papert, 1993). Bu beklentilerin çoğu gerçekleşmese de öğrencilerin matematiği daha iyi öğrenebilmeleri için bilgisayarın nasıl kullanılması gerektiği konusunda önemli bilgi ve deneyim oluşmuştur (Baki, 2001). Örneğin, kavramlara ilişkin özelliklerin ortaya çıkarılmasında, ölçüm yapabilmede, görselleştirmede, farklı örnekler üzerinde akıl yürütmede, ilişkilendirmede, iletişim becerilerinin geliştirilmesinde ve öğrencilerin kendi matematiksel yapılarını oluşturabilmesinde bilgisayarın nasıl kullanılması gerektiği ile ilgili tecrübe kazanılmıştır (Ertem-Akbaş, 2019; Sevimli \& Delice, 2015). İşte bu anlamada bilgisayar teknolojisinde yaşanan hızlı gelişmelerin matematik sınıflarına yansımaları olan dinamik geometri yazılımları (DGY) ve bilgisayar cebir sistemleri (BCS veya CAS), matematik eğitimindeki beklentilere ulaşabilmede önemli bir potansiyele sahiptir. Öğrencilerin soyut yapılar üzerine yoğunlaşabilmesi matematikte hayal etme gücünün artması, sezgi yolunun dolayısıyla keşfetme yollarının açılması demektir. Bu yollar ise öğrencilerin analiz yapma, varsayımda bulunma, genelleme yapma ve problem çözme becerilerini geliştirecektir (Baki, 2001). Bu bağlamda, öğretim faaliyetlerinde öğrenci merkezlilik esas alınarak öğrencileri bilginin pasif alıcısı konumundan bilginin aktif kurucusu konumuna taşınması önemli hale gelmektedir. Bilgisayar teknolojisinin böyle bir süreçte önemli bir potansiyele sahip olduğu birçok araştırmacılar tarafından dile getirilmektedir (Baki, 2008; Yılmaz, Ertem \& Güven, 2013).

Matematikte karşılaşılan birçok sembolik kavram formal olarak tanımlanmadan önce sınırlı olsa da kişilerin zihinlerinde sezgisel olarak mevcuttur. İlgili literatür incelendiğinde matematiksel sembolik kavramların birçoğunun öğrenciler tarafından güç kavrandığı ve yüzeysel olarak öğrenildiği belirtilmektedir (Chang \& Li 2005; Sevimli \& Delice, 2015). Analizde karşılaşılan "limit” kavramı bu kavramlardan biri olmakla birlikte ön öğrenmeleri üst düzey olan öğrencilerin bile zorlandığı bir kavram olarak karşımıza çıkmaktadır. Sürekliliği özel bir durum olarak içeren ve pek çok kavramın dayandığı limit kavramı, analizin çeşitli dallarında önemli rol oynamaktadır (Zengin, 2017). Limit ve süreklilik; matematiğin türev, integral gibi birçok önemli kavramının kazanılması için bilinmesi 
gereken en önemli ve temel kavramlardandır. Dolayısıyla bu kavramların öğrenciler tarafından anlamlandırılması önemlidir.

Limit-süreklilik gibi soyut ve öğrenilmesi zor olan temel kavramlarla ilgili karmaşık problemle karşılaşan öğrenci problemi çözme sürecinde teknoloji destekli öğrenme ortamında küçük gruplar halinde etkileşimli olarak sürece dâhil edildiğinde öğrencinin mantıklı çözüm yolları üretebileceği düşünülmektedir. Böyle ortamlarda öğrenciler hem sözlü hem de yazılı olarak ifade ettikleri fikirlerini uygulama olanağına sahip olacaklarından daha eleştirel düşünebilme ve bilgilerini analiz edebilme yeteneğine ulaşabileceklerdir (Castro, 2011). Böylece, limit ile ilgili günlük yaşamda edindikleri ön bilgilerle, okuldaki bilgilerini ilişkilendirerek kendi bilgilerini oluşturan öğrencilerde daha etkili öğrenme gerçekleşecektir. Dolayısıyla limit ve sürekliliğin kazanımları doğrultusunda öğretim sürecini daha etkili hale getirebilmek için neler yapılabileceğine odaklanılmalıdır. Bu bağlamda öğrencilerin cebir ve aritmetiksel metotlar kullanarak kolaylıkla sonuca ulaşmalarının mümkün olmadığı ileri düzey matematiksel düşünmeye geçişin göstergesi olan ve özellikle üniversite matematik müfredatının temelinde bulunan limit-süreklilik kavramının (Cornu, 1991) öğretiminde, öğretim sürecini etkili hale getirmek için teknoloji destekli öğrenme ortamları (Çavuş \& Eskitaşçıŏlu, 2016) oluşturulabilir.

Ülkemizde ortaöğretim eğitimini tamamlayıp üniversite giriş sınavında başarı gösteren öğrencilerin \%60'lık diliminin lisans programlarına devam ettiği düşünüldügünde üniversitelerimizde ve özel olarak meslek yüksekokullarımızda okutulmakta olan genel matematik dersinin içeriğinde yer alan limit-süreklilik kavramlarının öğretiminin ele alınması kaçınılmazdır. Genel veya temel matematik okuyan lisans öğrencilerine göre Meslek Yüksekokulu (MYO) öğrencilerinin limit ve süreklilik konularını öğrenmede çok daha sorunlu bir durumda olması bu geçişte yaşanabilecek birtakım zorlukları doğuracaktır. Özellikle bu kavramların öğretimi işlemsel ağırlıklı yapıldığında kavramsal anlama boyutu ihmal edileceğinden MYO öğrencilerinde öğrenme güçlükleriyle karşılaşılması kaçınılmazdır. Hâlbuki matematiksel işlemleri uygulama ve bunların pratiğini yapma fırsatı bulan öğrenci matematiği anlayıp-matematiksel düşünme gücü kazanabilir (Kokol-Voljc, 2000). Matematiksel işlemleri ve algoritmaları en iyi matematikçilerden bile daha hızlı ve güvenilir olarak uygulayabilen bilgisayar cebiri sistemleri (BCS) uygun konu eşliğinde uygun amaçlar için kullanıldığında bu işlem ve algoritmaların anlaşılması sağlanabilir (Kokol-Voljc, 2000). Araştırmalar, anlaşılması zor olan matematiksel kavramlarda 
karşılaşılan öğrenme güçlüklerinin aşılmasında BCS’lerin önemine vurgu yapmaktadır (Çelik, 2007; Kokol-Voljc, 2000). Böylece limit-süreklilik kavramlarının öğretimi esnasında karşılaşılacak öğrenme güçlüklerinin aşılmasında BCS’ler kullanılabilir.

BCS’yi sınıf ortamlarına taşımak öğrencilere çeşitli durumları temsil etme, sembol kullanma, sembolik gösterimlerle birlikte grafiksel-sayısal gösterimlerden yararlanma ve yorumlama olanağı da sunmaktadır. Dolayısıyla teknolojinin matematik eğitimine sunmuş olduğu bu imkânları öğrencilere sunabilmek için araştırmacı öğretmenin bu konuyu derinlemesine ele alması gerekmektedir.

$\mathrm{Bu}$ çalışmada ortaöğretim kurumlarının son sınıf müfredatı içerisinde yer almasına rağmen üniversiteye giriş sınavına hazırlanma kaygısıyla kavramsal anlama boyutunun ihmal edildiği görülen limit-süreklilik konusu ele alınmıştır. Özellikle temel matematik bilgisinden yoksun olan MYO'lar için genel matematiğin temel taşı olan limit-süreklilik konusundaki öğrenmeleri önemli görülmüştür. Bu konuları MYO öğrencilerinin etkili ve kalıcı öğrenmesini sağlamak amacıyla BCS'den Derive yazılımı kullanılarak oluşturulan öğrenme ortamı tasarlanmıştır. Çalışmada öğrencilerin bu ortamdaki limit-süreklilik konusundaki öğrenmelerini derinlemesine değerlendirmek amaciyla Biggs ve Collis (1991) tarafından geliştirilen genel bilişim modeli olarak tanımlanan SOLO taksonomisinin kullanılmasına karar verilmiştir. İlgili literatürde SOLO taksonomisinin özellikle öğrenme ortamlarıyla ilişkili olarak öğrencilerin bilgi ve becerilerini değerlendirmeye yönelik etkili bir model olduğu vurgulanmaktadır (Bigg \& Collis,1991; Çelik, 2007; Pegg \& Tall, 2005). SOLO taksonomisi ilköğretimden üniversiteye öğrencilerin belli kavramlarla ilgili matematiksel düşünme becerilerini tanımlamada ve yorumlamada çokça kullanılmıştır (Çelik, 2007; Jones, Thornton, Langrall, Mooney, Perry \& Putt, 2000).

Her öğrencinin limit-süreklilik kavramları ile ilgili düşünce ve yorumlama süreçleri belirli anlama düzeyleri tanımlanarak oluşturulabilir. $\mathrm{Bu}$ nedenle üniversitelerin $\mathrm{MYO}$ öğrencilerinin bilgisayar destekli öğrenme ortamında limit-süreklilik konusundaki öğrenmeleri SOLO taksonomisine göre değerlendirilebilir. Bu durumda MYO öğrencileri tarafından limit-süreklilik gibi anlamlandırılması zor olan kavramların öğretiminde teknolojik gelişmelerden istifade ederek oluşturulan öğrenme ortamlarının, MYO öğrencilerinde bu kavramlara ilişkin formel matematiksel bilgi ile tutarlı sezgisel bir yaklaşım gerçekleştirmesine imkân sunup sunmayacağı incelenebilir. İşte bu anlamda bu çalışma ile sunulan bilgiler çerçevesinde literatüre MYO öğrencileri özelinde bilgisayar 
destekli ortamda limit-süreklilik konusundaki öğrenmelerinin değerlendirilmesi bağlamında katkı sağlamayı amaçlamaktadır.

\section{Araştırmanın Amacı}

Bu çalışmada bir BCS yazılımı olan Derive programının kullanıldığı ortamda MYO öğrencilerinin limit-süreklilik konusundaki öğrenmelerinin SOLO taksonomisine göre değerlendirilmesi ve yorumlanması amaçlanmıştır.

\section{Araştırmanın Problemi}

$\mathrm{Bu}$ çalışmanın temel araştırma problemi; “BCS ile desteklenmiş öğrenme ortamında MYO öğrencileri limit-süreklilik konularını nasıl öğrenmektedir?" olarak belirlenmiştir. Bu problem çerçevesinde aşağıdaki alt problemlere cevap bulunmaya çalışılmıştır;

1. BCS destekli bir ortamda MYO öğrencilerinin "fonksiyonun belirsizlik durumlarında limit değerini bulabilme ile ilgili öğrenmeleri" SOLO taksonomisine göre hangi seviyededir?

2. BCS destekli bir ortamda MYO öğrencilerinin “fonksiyon grafiğini inceleyip sürekli olduğu aralıkları bulabilme ile ilgili öğrenmeleri" SOLO taksonomisine göre hangi seviyededir?

3. BCS destekli bir ortamda MYO öğrencilerinin "limit ile süreklilik arasındaki ilişki ile ilgili öğrenmeleri" SOLO taksonomisine göre hangi seviyededir?

Teorik Çerçeve

\section{Limit-Süreklilik Kavramı}

Artigue (2000) limit ve süreklilik kavramını matematiğin analiz dalının her konusuna değinen en temel kavram olarak ifade etmiştir. Sahip olduğu bu öneme karşın matematik öğretiminde yapılan çalışmalar, öğrencilerin cebir ve aritmetiksel metotlar kullanarak sonuca ulaşmada en çok zorlandığı kavramların limit ve süreklilik olduğunu göstermektedir (Cornu, 1991; Tall \& Vinner, 1981). İçerisinde sonsuzu ( $\infty$ ) içeren cebirsel işlemler barındıran ve öğrencilerin anlamada güçlük çekmesine neden olan limit ve sürekliliğin, ileri düzey matematiksel düşünmeye geçiş için temel olduğu bilinmektedir. İleri düzey matematik eğitimine başlayan öğrenciler limit ve sürekliliği dinamik (informal) ve statik (formal) olmak üzere iki şekilde kavramsallaştırmaktadır (Cornu, 1991; Tall \& Vinner, 1981). Dinamik form; Tall ve Vinner (1981) tarafından tanımlanmış olup " $x \rightarrow a \Rightarrow f(x) \rightarrow L$ ” ya da sözel olarak " $x$ 'ler $a$ 'ya yaklaşırken $f(x)$ 'ler $L$ 'ye yaklaşır" ifadesine dayanmaktadır. Matematik otoritelerince kabul edilen statik form ise; " $\lim _{x \rightarrow a} f(x)=L \Leftrightarrow \forall \varepsilon>0$ için $\exists \delta>0$ vardır $\exists\left|x-x_{0}\right|<\delta \Rightarrow|f(x)-L|<\varepsilon$ 
olur" şeklinde bilinen delta-epsilon limit tanımıdır. İlgili literatürde öğrencilerin bu iki tanımdan dinamik formu daha kolay kavramsallaştırdığına ulaşılmaktadır (Tall \& Vinner, 1981). Dinamik ve statik formunu verdiğimiz "limit" tanımını "süreklilik" tanımdan yola çıkıp sezgisel ve grafiksel olarak yorumlayacak olursak; " $f$ " bir fonksiyon olsun o halde " $x$, $a^{\prime}$ ya yaklaştığında, $f(x)$ 'in limiti" dediğimiz şey aslında " $x$, a'ya çok çok yaklaştığında, $f(x)^{\prime}$ in belli bir sayıya çok çok yakın olup olmayacağı, oluyorsa hangi sayıya çok çok yakın olacağ1"nı irdelemekle eşdeğerdir.

Grafiği aşağıdaki gibi olan " $\mathrm{a}<\mathrm{c}<\mathrm{b}$ ve $\mathrm{f}:[\mathrm{a}, \mathrm{b}] \backslash\{\mathrm{c}\} \rightarrow \mathrm{R}$ ” fonksiyonunu incelersek;

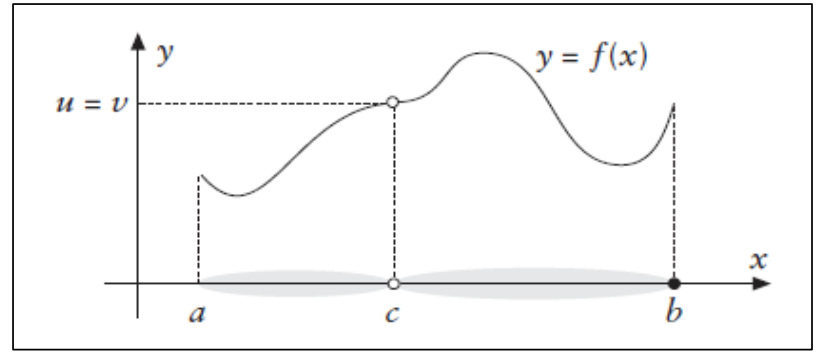

Şekil 1. "a $<\mathrm{c}<\mathrm{b}$ ve $\mathrm{f}:[\mathrm{a}, \mathrm{b}] \backslash\{\mathrm{c}\} \rightarrow \mathrm{R}$ " fonksiyonunda " $\mathrm{u}=\mathrm{v}$ " durumunun grafiği

Şekil 1'de c noktası her ne kadar $[a, b] \backslash\{c\}$ kümesinde tanımlı olmasa da bu nokta fonksiyonun bir yoğunlaşma noktası olup x, c'ye giderken fonksiyonun limiti incelenebilir. Böylece limiti incelenecek olan sayının fonksiyonun tanım kümesinde olma zorunluluğu yoktur. Fonksiyonda $x, c^{\prime} y e$ küçük değerlerden yaklaştığında, $f(x)$ değeri u=v'ye yaklaşırken, $c^{\prime}$ ye büyük değerlerden yaklaşırken $f(x)$ değerinin $u=v^{\prime}$ ye yaklaştı̆ğ görülmektedir. $O$ halde burada limitin varlığından söz edilebilir. Fakat " $f(c) \neq(u=v)$ " olduğundan bu fonksiyon c noktasında sürekli olmayacaktır.

Buraya kadar değinilen içerik, limit ve sürekliliğin matematiksel tanımına sezgisel olarak yaklaşımı ele almıştır. Bu yaklaşım MYO öğrencileri için "grafiksel (görsel) ve dinamik limit-süreklilik tanımı" olarak isimlendirilecektir. Öğrencilerin formal olarak limit ve sürekliliği kavramsallaştırmada zorlandıklarına ve formal tanımı formül olarak ele aldıkları ilgili literatürde belirtimektedir (Tall \& Vinner, 1981). Öğrencilerin özel olarak MYO öğrencilerinin matematiksel notasyonlarla kavramsallaştırmada güçlük çektiği limitsüreklilik konusu sezgisel yaklaşımlar yoluyla dinamik ortamlarda grafiksel (görsel) çalışmalarla limit-sürekliliği kavramsallaştırarak öğrenmeleri şeklinde değerlendirilecektir.

MYO'da Matematik Öğretimi ve SOLO Taksonomisi

Matematik dersinin mantık ve düşünmeye yön veren özelliklerin gelişmesinde etkili olması, bireyler tarafından kazanılması gereken mesleki gelişim açısından önemli 
görülmektedir. Mesleki gelişim yeterliğine sahip olan birey, nitelikli iş gücü sayesinde iyi bir performans sergilemenin yanı sıra düşünen, öğrenen ve üretendir. Nitelikli iş gücüne sahip olmanın yolu ise iyi planlanmış mesleki eğitimle mümkündür. $\mathrm{Bu}$ anlamda lisans ve ön lisans düzeyinde eğitim veren Mesleki ve Teknik Eğitim kurumları ile ortaöğretim kurumlarının hedef aldığı istihdam sahaları arasında kalan boşluğu doldurma işlevini yerine getiren üniversitelerin Meslek Yüksekokullarına önemli rol düşmektedir (Karadeniz \& Kelleci, 2015).

Mesleki ve Teknik Eğitim Sistemi yükseköğrenimde iki yıllık Meslek yüksekokulları ve dört yıllık mesleki ve teknik eğitim fakülteleri aracıllğıyla yürütülmektedir. Meslek ve Teknik Eğitim Sistem'inin en önemli aşamalarından olan Meslek Yüksekokulları sanayi, ticaret ve hizmet sektörlerine yeterli bilgi ve beceriyle donanmış ara eleman yetiştirmek amacıyla kurulmuştur. Böylece nitelikli eleman yetiştirmenin ve elemanların soyut düşünme becerilerinin önemi ortaya çıkmaktadır. Bu bağlamda düşünmeyi geliştirdiği bilinen matematik öğretimi ve öğrenimi önem kazanmaktadır. Bu önem doğrultusunda ülkemizde ortaöğretim eğitimini tamamlayıp üniversite giriş sınavında başarı gösteren öğrencilerin \%40’lık diliminin ön lisans programlarına devam ettiği düşünüldüğünde üniversitelerimizin meslek yüksekokullarında okutulmakta olan genel matematik dersinin içeriğinde yer alan kavramların öğretiminin ele alınması kaçınılmazdır. Bu doğrultuda soyut bir yapıya sahip olan matematiğin öğrenme ve öğretilmesinde yenilikler yapılarak somutlaştırılması gerektiği vurgulanmıştır (Akbulut \& Işık, 2005). Bu durum matematik öğrenme-öğretme etkinliklerinin ortaya konuş biçiminin ne kadar önemli olduğunu göstermektedir. Oysa ortaöğretim kurumlarının son sınıf müfredatı içerisinde yer almasına rağmen üniversiteye giriş sınavına hazırlanma kaygısıyla kavramsal anlama boyutunun ihmal edildiği görülen limit-süreklilik kavramları için bu önemin dikkate alınmadığı görülmektedir. Örneğin; sonsuzluğu bir sayı olarak algılayan MYO öğrencileri belirsiz olan bir fonksiyonun sürekli olabileceğini düşünmektedir. Ayrıca ortaöğretimi bitirinceye kadar fonksiyon grafiği incelemeyen MYO öğrencileri formal olarak tanımlanan limit-süreklilik kavramlarını işlemsel olarak karşılaştıkları herhangi bir probleme uyarlamakta da zorluk çekmektedir. Açıkçası öğrenciler ezberledikleri bilgi parçalarını bile yeterli düzeyde anlamlandıramamaktadır. Buradan anlaşıldığı üzere bu çalışma kapsamında araştırmacı öğretmen yeteneği ölçüsünde, Meslek Yüksekokullarında okutulan ve kavramsal anlama boyutunun ihmal edildiğini gözlemlediği genel matematiğin temel konuları niteliğinde olan 
limit, türev ve integral konularının kavramsal temelini oluşturan limit ve süreklilik kavramlarına ilişkin tasarladığı bilgisayar destekli öğrenme ortamında öğrencilerin soyut düşünme becerilerini geliştirmeye çalışmıştır.

Biggs ve Collis tarafından geliştirilen genel bilişim modeli olarak tanımlanan SOLO (Structure of the Observed Learning Outcomes) taksonomisinin, özellikle ilköğretimden üniversiteye öğrencilerin belli kavramlarla ilgili matematiksel düşünme becerilerini tanımlamada ve yorumlamada, bilişsel bilgi ve becerilerini değerlendirmede etkili bir araç olarak çokça kullanıldığı görülmektedir (Jones ve diğ., 2000). SOLO öğrencilerin belirli görevlere verdikleri cevapları nitelik yönünden analiz etmek için hiyerarşik bir model sunmaktadır (Pegg \& Tall, 2005). Ayrıca SOLO taksonomisinin özellikle öğrenme ortamlarıyla ilişkili olarak öğrencilerin bilgi ve becerilerini değerlendirmeye yönelik etkili bir model olduğuna ulaşmaktayız (Bigg \& Collis,1991; Pegg \& Tall, 2005). Özellikle amacı tüm süreci görme isteği ve öğrencilerin vermiş olduğu cevapların niteliğini ölçme olan çalışmalarda öğrencilerin düşünme becerilerini sınıflandırmak açısından SOLO'nun uygun bir değerlendirme olduğu söylenebilir. Bu bağlamda çalışmaların sonucunda öğrenci cevaplarının var oldukları düzeyden belirlenen üst düzeylere geçmesinde, kavramlara yükledikleri anlamların işlemsel boyuttan uzaklaşarak daha temsil edici ve daha yorumlayıcı olmasında, öğretmenlerin öğrencilere sundukları öğrenme ortamlarının, deneyimlerin ve fırsatların önemine değinerek tüm süreci görmeye olanak sunması SOLO taksonomisinin tercih edilmesinde etken olmuştur.

Yapılan literatür taraması sonucunda öğrencilerin limit-süreklilik kavramlarına ilişkin ne öğrendiklerini incelemek için genel olarak deneysel desenin kullanıldığı ve nitel verilerin desteği ile olguların bağlı bulundukları öğrenme ortamlarının yorumlandığı görülmektedir. Bu çalışmaların ortak amaçları öğrencilerin belirtilen ortamlarda ne kadar öğrendiğini ve ne öğrendiğini betimlemek olduğundan bu çalışmalar için seçilen değerlendirmeler makul olabilir. Oysa esas amacın MYO öğrencilerinin ne kadar öğrendiğini ve ne öğrendiğini betimlemekten çok nasıl öğrendiklerini anlamak olan bu çalışmada öğrencilerin öğrenmelerini değerlendirirken ve yorumlarken tercih edilen modelin SOLO Taksonomisi olarak seçilmesi uygun görülmüştür. Böylece öğrenci cevaplarından anlam çıkarırken "ne oldu?, ne oluyor?, ileride ne olacak?, en iyi nasıl anlayabiliriz?, bu bilgiye nasıl ulaşılmıştır?" gibi sorulara cevap aranmasının yanı sıra öğrenme çıtılarının SOLO taksonomisinin hangi seviyesine karşılık geldiğine de odaklanılacaktır. 
SOLO modelinin düşünme evreleri incelendiğinde soyut (formal) evre erken yetişkinlik dönemine denk gelmektedir (Biggs \& Collis, 2014). Limit-süreklilik kavramlarının anlamlandırılması soyut düşünme becerisi gerektirdiğinden ön lisans öğrencileri olan MYO öğrencilerinin de soyut evrede yer aldığı varsayılmış ve yapılacak olan bu çalışma için uygun görülmüştür.

\section{Yöntem}

\section{Araştırmanın Modeli}

$\mathrm{Bu}$ çalışma, üniversitelerin meslek yüksekokullarında okutulan genel matematik derslerindeki limit-süreklilik konusunun öğretiminde öğrencilerin BCS'den Derive programı ile desteklenmiş öğrenme ortamında öğrenmelerini değerlendirmek amacıyla yürütülmüş ve tamamlanmış bir doktora tezinin bir bölümünü rapor etmektedir. Doktora çalışmasında geliştirilip uygulanan çalışma yaprakları 5 soru grubu ve 18 alt çalışma sorusunu kapsamıştır (Ertem-Akbaş, 2016). Bu çalışmada ise 3 soru grubu ve 3 alt çalışma sorusu ele alınmıştır. Araştırma, uygulamada karşılaşılan sorunlara çözüm üretme amacı taşıdığından eylem araştırması olarak desenlenmiştir. Nitel araştırma yaklaşımlarından biri olan eylem araştırması diğer bir adı ile araştırmacı öğretmen yöntemi gerçek sınıf ortamında öğretimin niteliğini arttırma ve geliştirmeye yönelik süreç olarak tanımlanmaktadır (Johnson, 2005). Mills'e (2003) göre araştırmacı öğretmen yöntemi, öğrenme/öğretme ortamında öğretmen araştırmacıların, öğrencilerinin daha iyi nasıl öğrenebilecekleri ile ilgili bilgilenmek amacıyla gerçekleştirdikleri sistematik bir araştırma sürecidir. Ayrıca nitel araştırmada vurgulanan "araştırmacının katılımcı rolü ve aynı zamanda veri toplama aracı olması" durumunun araştırmacı öğretmen yönteminde kendini göstermesi (Yıldırım \& Şimşek, 2013) sonucu bu araştırmada en uygun yöntemin araştırmacı öğretmen yöntemi olacağına karar verilmiştir. MYO öğrencilerinin bilgisayar destekli öğrenme ortamında BCS'den Derive yazılımını kullanarak "limit-süreklilik" konusunu öğrenmelerini değerlendirmeyi amaçlayan bu çalışmada, uygulayıcı aynı zamanda araştırmacıdır. Bu kapsamda araştırmacı BCS destekli çalışma yaprakları ve eylem planı geliştirerek uygulamalar yapmış ve öğretim sürecindeki MYO öğrencilerinin öğrenmelerini değerlendirmiştir. Bu bağlamda çalışmada nitel araştırma yaklaşımlarından biri olan araştırmacı öğretmen yöntemi (action research) (eylem araştırması) kapsamında Mills (2003) tarafından belirlenen dört aşamalı eylem araştırması döngüsü kullanılmıştır. 


\section{Çalışma Grubu}

Araştırmanın çalışma grubunu Türkiye'nin doğusunda yer alan bir devlet üniversitesinin bir Meslek Yüksekokulu'nda öğrenim gören ve “Genel Matematik-2" dersini alan 12'si kız 20'si erkek olmak üzere toplam 32 öğrenci oluşturmaktadır. Çalışma BCS destekli çalışma yaprakları ve eylem planı geliştirip hem araştırmacı hem de dersin hocası rolünde olan araştırmacılardan biri ile MYO öğrencileri üzerinde gerçekleştirilmiştir. Dolayısıyla bu çalışmanın katılımcıları belirlenirken çalışmanın amacına bağlı olarak araştırmacıya kolay ulaşılabilirlik, zaman ve maliyet açısından avantaj sağlayan kolay ulaşılabilir örnekleme (Miles \& Huberman, 1994) yöntemi tercih edilmiştir. Nitekim bu çalışma, dersin hocasının araştırmacı olduğu bir eylem araştırması olması ve dersini yürüttüğü MYO öğrencileri ile çalışılması bağlamında kolay ulaşılabilir örnekleme için uygun özellikler taşıdığı düşünülmektedir. Ayrıca çalışmada sürece dâhil olan öğrenci isimleri öğrencilerin gerçek isimleri değildir. Diyaloglarda ise öğrencileri temsil etmek amacıyla kullanılan isimlerin baş harfleri kullanılmıştır.

\section{Veri Toplama Araçları}

Eylem araştırmasında veriler gözlem, görüşme ve dokümanlar yoluyla toplanır. Bu kategorilerden elde edilen veriler çalışmanın veri setini oluşturur (Philips \& Carr, 2009). Bu araştırmada veriler 2016 yılında öğretim süresince uygulanan çalışma yaprakları (bu çalışma yapraklarındaki öğrenci notları), öğrencilerin bilgisayar ekran çıktıları (Derive yazılımı üzerinde yaptıkları çalışmalar), gözlemler, gözlemler esnasında araştırmacı öğretmenin tuttuğu notlar, çalışma boyunca öğrencilerle geçen diyaloglar ve veri kaybını önlemek için bazı diyalogların ses kaydı yardımıyla toplanmıştır.

$\mathrm{Bu}$ çalışma kapsamında ele alınan çalışma yaprakları araştırmada odaklanılacak konular dikkate alınarak BDÖ’ye yönelik hazırlanmıştır (Ertem-Akbaş, 2016). Çalışma yapraklarının hazırlanmasında dikkat edilmesi gereken özelliklerden biri bilginin öğrenciye doğrudan aktarılmadan ipucu niteliğindeki sorularla öğrencileri bilgiyi keşfetmeye ve sonuçlara ulaşarak genelleme yapmaya ulaştırabilir olmasıdır (Baki, 2008). Bu amaçla hazırlanan çalışma yaprakları öğrencilerin kafasında canlandırdığı matematiksel işlemin ekranda bir matematiksel nesne olarak karşılarına çıkmasını sağlayabilecek nitelikte hazırlanmıştır. Böylece öğrencilerde matematiksel düşünme ve soyutlama kapasitesi artacak ve ortaya daha kavramsal bir matematiğin çıkacağı düşünülmüştür. Aşağıdaki tabloda bu 
çalışmada ele alınan çalışma yaprakları ile hedeflenen kazanımlar ve stratejik hedeflere yer verilmiştir.

Tablo 1. Çalışma yaprakları ile hedeflenen kazanımlar ve stratejik hedefler

\begin{tabular}{|c|c|c|c|}
\hline $\begin{array}{l}\text { Çalışma } \\
\text { Yaprağ1 }\end{array}$ & Kavramsal İpuçları & Hedef Kazanımlar & Stratejik Hedefler \\
\hline Çlş.Yp-3 & $\begin{array}{l}\text { Fonksiyon kavramı, } \\
\text { çarpanlara ayırma, } \infty \\
\text { kavramı, belirsizlik } \\
\text { durumları ve limit } \\
\text { kavramı }\end{array}$ & $\begin{array}{l}\text { - Fonksiyonun belirsizlik } \\
\text { durumlarında limit değerini } \\
\text { bulur } \\
\text { - Fonksiyon grafiğini inceler }\end{array}$ & $\begin{array}{l}\text { - Gerçek değerli fonksiyonlarda } \\
\text { sonsuz için limit değerini grafik } \\
\text { üzerinde açıklar ve uygulamalar } \\
\text { yapar } \\
\text {-Verilen noktada } \frac{\infty}{\infty} \text { belirsizlik } \\
\text { durumunu açıklar ve } \\
\text { fonksiyonun limitini hesaplar }\end{array}$ \\
\hline Çlş.Yp-5 & $\begin{array}{l}\text { Fonksiyon kavramı, } \\
\text { çarpanlara ayırma, } \infty \\
\text { kavramı, belirsizlik } \\
\text { durumları ve limit } \\
\text { kavramı }\end{array}$ & $\begin{array}{l}\text { - Fonksiyonun belirsizlik } \\
\text { durumlarında limit değerini } \\
\text { bulur } \\
\text { - Fonksiyon grafiğini inceler }\end{array}$ & $\begin{array}{l}\text { - Trigonometrik fonksiyonların } \\
\text { limitini grafik üzerinde açılar } \\
\text { ve uygulamalar yapar } \\
\text {-Verilen noktada } 0 . \infty \text { belirsizlik } \\
\text { durumunu açılar ve } \\
\text { fonksiyonun limitini hesaplar }\end{array}$ \\
\hline Çlş.Yp-10 & $\begin{array}{l}\text { Fonksiyon kavramı, } \\
\text { çarpanlara ayırma, } \infty \\
\text { kavramı, belirsizlik } \\
\text { durumları, limit ve } \\
\text { süreklilik kavramı }\end{array}$ & $\begin{array}{l}\text { - Fonksiyonun grafiğini } \\
\text { inceler ve sürekli olduğu } \\
\text { aralıkları bulur } \\
\text { - Fonksiyonun tanımsız } \\
\text { olduğu noktalarda süreklilik } \\
\text { aranamayacağını söyler } \\
\text { - Limit ile süreklilik arasında } \\
\text { ilişki kurar }\end{array}$ & $\begin{array}{l}\text { - Fonksiyonun verilen bir } \\
\text { noktada sürekli ya da süreksiz } \\
\text { olduğunu belirler grafik } \\
\text { üzerinde açıklar } \\
\text { - Süreksizlik çeşitlerini } \\
\text { hatırlayarak "sonsuz } \\
\text { süreksizliği" ifade eder ve grafik } \\
\text { üzerinde açıklar }\end{array}$ \\
\hline
\end{tabular}

\section{Verilerin Analizi}

Nitel çalışma yapan araştırmacılar veri analiz yöntemlerinin standart hale getirilemeyeceğini (Strauss, 1987), toplanan verinin özgün formuna sadık kalınarak, gerektiğinde katılımcıların söylediklerinden doğrudan alıntı yaparak, açıklayıcı sonuçlara ulaşmak amacıyla bazı temalar ve temalar arası ilişkiler belirlenerek sistematik analiz yapılması gerektiğini önermiştir (Wolcott, 1994'ten aktaran: Yıldırım \& Şimşek, 2013). Genel olarak önerilerde ortak olan ve en çok göze çarpan nokta, verilerin betimlenmesi ve temaların ortaya çıkarılmasına verilen önemdir (Yıldırım \& Şimşek, 2013). Bu önem dikkate alınarak elde edilen nitel veriler üç grupta analiz edilmiştir.

MYO Öğrencilerinin Her Bir Soru Grubunda Limit-Süreklilik ile İlgili Öğrenme Seviyelerinin Belirlenmesinde İzlenen Yol

Bu çalışma için temel veriler öğrencilerin öğrenme çıktılarından elde edilen verilerdir. Bu süreçte çalışma yapraklarına verilen cevaplar araştırma sorularına cevap bulabilmek için gruplandırılan her bir soru grubunda ayrı ayrı incelenmiştir. Aşağıda bu çalışma kapsamında ele alınan çalışma yapraklarında yer alan soruların (3 soru grubu ve 3 alt çalışma soru grubu) gruplandırılmasına ilişkin tabloya yer verilmiştir: 
Tablo 2. Çalışma yapraklarında yer alan soruların gruplandırılması

\begin{tabular}{cccl}
\hline $\begin{array}{c}\text { Soru } \\
\begin{array}{c}\text { Grubun } \\
\text { Adı }\end{array}\end{array}$ & $\begin{array}{c}\text { Çalışma } \\
\text { Yaprağı }\end{array}$ & $\begin{array}{c}\text { Alt Çalışma } \\
\text { Soru Grupları }\end{array}$ & Soru Grubunun Hedef Kazanımı \\
\hline $\begin{array}{c}\text { Birinci Soru } \\
\text { Grubu }\end{array}$ & 3 & 5,6 & $\begin{array}{l}\text { Fonksiyonun Belirsizlik Durumlarında Limit Değerini } \\
\text { Bulur }\end{array}$ \\
\hline $\begin{array}{c}\text { İkinci Soru } \\
\text { Grubu }\end{array}$ & 5 & 6,7 & $\begin{array}{l}\text { Fonksiyon Grafiğini İnceleyip Sürekli Olduğu } \\
\text { Aralıkları Bulur }\end{array}$ \\
\hline $\begin{array}{c}\text { Üçüncü } \\
\text { Soru Grubu }\end{array}$ & 10 & 2,3 & Limit İle Süreklilik Arasında İlişki Kurar \\
\hline
\end{tabular}

Bu gruplandırma dikkate alınarak elde edilen veriler yazıya dönüştürülerek araştırma soruları doğrultusunda defalarca okunmuştur. Araştırma sorularına cevap olabilecek veriler veri setinden seçilmiştir. Bir soruya başka sorularda cevap olabilecek yanıtlar, ilgili olduğu grubun altında toplanmıştır. Verilerin incelenmesi sürecinde her bir öğrencinin vermeye çalıştığı mesajlar kodlanarak anlam bazında ortak temalar gruplandırılmıştır. Böylece her öğrenci için her problem durumunu kapsayan vignetler yazılmıştır (Çelik, 2007). Daha sonra bu vignetler her bir soru grubu için bir araya getirilerek karşılaştırmalı olarak değerlendirilmiş ve rubrikler oluşturulmuştur. Bu süreçte araştırmacı öğretmen ile birlikte, SOLO taksonomisi hakkında bilgi sahibi olan bir başka araştırmacı rol almıştır. Araştırmacı öğretmen ile diğer araştırmacı birbirinden bağımsız şekilde rubriklerden yararlanarak MYO öğrencilerinin çalışma yapraklarındaki her bir aşama ile ilgili cevaplarını vignetler ışığında bir seviyeye atamıştır. Böylece araştırmacı öğretmenin araştırma problemi doğrultusunda gruplandırdığı çalışma yapraklarındaki sorulara verilen cevaplar, öğrencilerin ekran çıktıları ve ders sürecindeki diyaloglardan elde edilen veriler, diğer araştırmacı ile tekrar okunarak MYO öğrencileri için en uygun düşünme seviyesi belirlenmiştir. Oluşturulan seviyelendirmeler araştırmacı öğretmen ve diğer araştırmacı ile tekrar kontrol edilirken anlaşmazlığa düştükleri (cevabın farklı seviyelere yerleştirilmesi) durumlarda her iki araştırmacı cevabın en uygun olduğu seviyede uzlaşıncaya kadar tartışmaya devam etmiştir. Ayrıca SOLO taksonomisi hakkında bilgi sahibi olan bir başka uzmanın görüşlerine danışarak uzlaştıkları seviyeyi doğrulamışlardır. Çünkü ayrı ayrı belirlenen seviyelerin ortalamasını almak öğrencinin gerçek anlamdaki seviyesini temsil etmiş olmayacaktı (Çelik, 2007).

Araştırmacı öğretmen ve diğer araştırmacı arasındaki güvenirliğin araştırılmasında Miles ve Huberman'ın (1994) güvenirlik formülü kullanılarak anlaşma yüzdesi hesaplanmıştır. Böylece bu çalışmanın anlaşma yüzdesi \%85 olarak hesaplanmıştır. Miles ve 
Huberman'a (1994) göre \%70 ve üzerinde bir yüzdenin güvenilir bir kodlama olduğu düşünüldüğünde, bu çalışmada SOLO taksonomisinin seviyeleri temel alınarak geliştirilen rubriğin tutarlı ve güvenilir seviyelendirme yapmaya uygun olduğunu görmekteyiz.

MYO Öğrencilerinin Limit-Süreklilik ile İlgili Öğrenmelerinin Ortalama Seviyesinin Belirlenmesinde İzlenen Yol

Nitel veriler temelde basit yüzde hesapları ve sözcük sıklık hesapları olarak iki yöntemle sayısallaştırılabilir (Yıldırım \& Şimşek, 2013). Bu çalışmada araştırmacı öğretmen, MYO öğrencilerinin bilgisayar destekli öğrenme ortamında "limit-süreklilik" konusunu öğrenebilmelerine ilişkin genel bir bakış sunmaktadır. Bu genel bakışı daha esnek sunabilmek amacıyla aşağıda açıkladığı şekilde basit hesaplamalardan yararlanmıştır.

Kodlamalar anlam bazında ortak temalar halinde gruplandırılırken oluşturulan vignetlerdeki veriler yardımıyla dikkatli bir şekilde tamamlanan analiz sürecinde öğrencilerin çalışma yapraklarına verdikleri cevaplar SOLO taksonomisine bağlı rubrikler olarak sayısal bir ölçekleme (1-5) yardımı ile sınıflandırılmıştır (Çelik, 2007). Rubriklerde 1 yapı öncesi (YÖ), 2 tek yönlü yapı (TY), 3 çok yönlü yapı (ÇY), 4 ilişkilendirilmiş yapı (IY) ve 5 soyutlanmış yapı (SY) seviyesindeki bir cevabı göstermektedir (Çelik, 2007). Bu seviyeler MYO öğrencilerinin bilgisayar destekli öğrenme ortamında limit-süreklilik konusunu öğrenebilmeleriyle ile ilgili ortalama seviyelerini belirlemede yardımcı olmuştur. Ayrıca öğrenci cevaplarından bazılarının SOLO seviyesine ilişkin özellikleri taşıdığı halde sınıflandırmanın altında ya da üstünde kaldığı görülmüştür. Bu tip cevapları belirli hale getirebilmek için seviyenin altında olan cevapların sayısal kodunun önüne "“_ işareti; seviyenin üstünde olan cevapların sayısal kodunun önüne “+” işareti konmuştur. Bu sayısal olarak 0.25 puan artışını veya azalışını göstermiş olacaktır. Örneğin, düşük ilişkilendirilmiş yapı seviyesindeki bir cevap 4- ile gösterilecek ve hesaplamalarda 3.75 puan olarak alınacaktır. Benzer şekilde yüksek ilişkilendirilmiş yapı seviyesindeki bir cevap 4+ ile gösterilecek ve hesaplamalarda 4.25 puan olarak alınacaktır (Çelik, 2007).

Diyaloglardan Elde Edilen Verilerin Analizi

Araştırmacı öğretmen öğrencilerin yaşadığı öğrenme deneyimlerini derinlemesine değerlendirebilmek için ders sürecinde öğrencileri ile sürekli diyalog halinde olmuştur. Bu süreçte gerektiğinde açıklayıcı notlar ve ses kaydı almıştır. Bu notlar ve kayıtlar defalarca okunup dinlenerek araştırmanın amacı doğrultusunda gerekli olan veriler yazılmış ve diğer verilerle karşılaştırmalı olarak yorumlanmıştır. Ayrıca MYO öğrencileriyle gerçekleşen 
diyaloglarda öğrencilerin limit-süreklilik konusundaki öğrenme çıktılarının BCS kullanımı ile nasıl gelişim gösterdiğine odaklanılmıştır. Bu gelişim BCS destekli öğrenme ortamında MYO öğrencileriyle gerçekleşen diyaloglardan elde edilen doğrudan alıntılarla desteklenmiş ve SOLO taksonomisinin hangi düzeylerine karşılık geldiği rubrikler yardımıyla yorumlanmıştır.

\section{Geçerlik ve Güvenirlik}

Eylem araştırmalarının verileri kendine özgüdür ve bağlamsaldır. Bu yöntemdeki geçerliliği test edecek kriterleri Lincoln, Lynham ve Guba (2011) iç geçerlik yerine inanılırlık, dış geçerlik yerine aktarılabilirlik (transfer edilebilirlik), iç güvenirlik yerine tutarlılık ve dış güvenirlik yerine ise doğrulanabilirlik (teyit edilebilirlik) kavramlarını kullanarak düzenlemişlerdir.Bu çalışmada inanırlığı sağlamak için çalışma boyunca MYO öğrencilerinin yaşantıları ve ortamdaki etkileşimlere ait gözlemler araştırmacı notları olarak kaydedilmiş, öğrencilerle yapılan diyalogların bazıları ses kayıt cihazı ile kayıt altına alınmış, öğrencilerin üzerinde çalıştığı çalışma yaprakları ve ekran çıktıları araştırmacı öğretmen tarafından derinlemesine incelenip saklanmıştır. Ayrıca öğrenme ortamında yaşananların betimlenmesinde ve yorumlanmasında araştırmacı öğretmen ön yargılarından arınmaya gayret göstermiş ve nesnel olmaya dikkat etmiştir. Aktarıabilirlik için, yapılan çalışmalar, uygulandığı ortam, araştırma grubu ve uygulama süreci mümkün olduğunca ayrıntılı olarak betimlenmeye çalışılmış ve bulgular doğrudan alıntılarla desteklenerek yaşanan süreç canlandırılmaya çalışılmıştır. Tutarlılık için, tasarlanan bilgisayar destekli öğrenme ortamında öğrencilerle ders sürecinde geçen diyaloglardan, öğrencilerin çalışma yapraklarından, ekran çıtılarından, araştırmacı öğretmenin öğrenci ile ilgili gözlemlerinden ve notlarından elde edilen veriler incelenip öğrencilerin limit-süreklilik konusu ile ilgili öğrenmeleri SOLO seviyelerine bağlı olarak anlaşılmaya çalışılmış ve tartışılmıştır. Doğrulanabilirlik için tüm süreç, veri toplama araçları, analiz süreci ayrıntılı açıklanmış, elde edilen bulgular ve sonuçlar doğrudan alıntılarla desteklenerek teyit edilebilirlik sağlanmaya çalışılmıştır.

\section{Öğretim Süreçleri}

Bilgisayar destekli öğrenme ortamını tasarlamak için çalıştığı MYO'nun bilgisayar laboratuvarını kullanmayı uygun gören araştırmacı öğretmen bu ortamda MYO öğrencileri ile 5 haftalık ders akışı süreci ile bahar dönemini tamamlamıştır. Bu sürecin sonunda yeni eğitim-öğretim yılının güz döneminin ilk 2 haftasında da aynı öğrenci grubuyla aynı çalışma 
yapraklarını tekrarlamıştır. Yeni dönemdeki dersler yine aynı öğrenme ortamında (bilgisayar laboratuvarında) yürütülmüştür. Öğrencilere aynı çalışma yapraklarının uygulanmamış kopyaları dağıtılmıştır. Ders akışı boyunca çalışma yapraklarında yer alan sorularla meşgul olan öğrenciler istedikleri zaman istedikleri şekilde Derive yazılımını kullanma imkânına sahip olmuşlardır. Çalışma kapsamında MYO öğrencileriyle toplam 7 haftalık ve 20 saatlik ders akışı sürdürülmüştür. Öğrencilerin limit-süreklilik konusu ile ilgili öğrenmelerini derinlemesine anlamayı düşünen araştırmacı öğretmen, 7 haftalık çalışma süresince hem araştırmacı hem de dersin hocası rolünü üstlenmiştir. Bu doğrultuda uygulanan öğretim süreci ve araştırmacı rolü aşağıdaki gibi özetlenebilir;

1. Ders akışı öncesi bilgisayar laboratuvarının bilgisayarlarını inceleyerek ders akışında kullanacağ1 “Derive” yazılımını her dönem formatlanan bilgisayarlara yüklemiştir.

2. Öğrencilerin “Derive” yazılımını etkili kullanabilmesi için programın menülerini, menülerdeki araçları ve bu araçların özelliklerini içeren bir kılavuz oluşturmuştur.

3. Ders akışı kapsamında 1. hafta (3 saat), limit-süreklilikle ilgili kavramsal ipuçları içeren konu özeti yaptıktan sonra Derive Yazılımı Tanıtım Kılavuzu'nu dağıtıp yazılıma kısaca değinmiştir.

4. 2. hafta (3 saat), öğrencilerin hazırlanan bilgisayar destekli öğrenme ortamına uyum sağlaması ve yazılımı tanıması için oluşturduğu kılavuz yardımıyla limit bulma, grafik çizme, süreklilik inceleme gibi uygulamalar yaptırmıştır. Bu süreçte öğrenciler aktif olarak serbest çalışma yaparken araştırmacı öğretmen yol gösterici rol üstlenmiştir.

5. 3., 4. ve 5. haftalar (9 saat) uygulanan çalışma yaprakları ile öğrencilerin belirlenen hedef kazanımlara ulaşmasını sağlamaya çalışmıştır. Bu süreçte araştırmacı öğretmen; ortam ile ilgili aksaklıkları gideren, öğrencilerin öğrenme süreçlerini gözlemleyen, sorulan sorulara göre açıklayıcı ve yol gösterici rolünü üstlenmiştir.

6. Yeni dönemde 6. ve 7. haftalar (5 saat); araştırmacı öğretmen hem elde ettiği verileri güçlendirebilmek hem de öğrencilerin düşünme biçimlerindeki gelişimi karşılaştırabilmek için güz dönemine ait ilk iki hafta aynı öğrenci grubu ile aynı ortamda aynı çalışma yapraklarını tekrar çalışmıştır. Bu süreçte araştırmacı öğretmen çalışmanın tutarlığını sağlayıcı rol üstlenmiştir.

\section{Bulgular}

Meslek yüksekokulu öğrencilerinin BCS ile desteklenmiş öğrenme ortamında “limitsüreklilik" konusundaki öğrenme çıktılarını SOLO taksonomisine göre değerlendirmeyi 
amaçlayan bu çalışmanın bulguları çalışmanın alt problemleri çerçevesinde üç başlık altında sunulmuştur. Bu alt başlıklar altında öğrencilerin verdiği cevapların betimsel analizi ve SOLO taksonomisine göre hangi seviyeye yerleştirildiği gerekçeleri ile birlikte sunulmuştur. Çalışma kapsamında geçen MYO öğrenci isimleri MYO öğrencilerinin gerçek isimleri değildir. Bu öğrencileri temsil etmek için kullanılan isimler araştırmacı öğretmen tarafından belirlenmiştir. Diyaloglarda araştırmacı öğretmene ait konuşmaları temsil etmek için "AÖ", katılımcı MYO öğrencilerine ait konuşmaları temsil etmek için ise o öğrencinin isminin baş harfi kullanılmıştır. Öğrencinin konuşmasına ara verdiği veya düşündüğü süreçler ise diyaloglarda “......" şeklinde gösterilmiştir.

Fonksiyonun Belirsizlik Durumlarında Limit Değerini Bulabilme ile İlgili Bulgular

Bu başlık altında Birinci Soru Grubu kapsamında ele alınan 3. çalışma yaprağının 5., 6. soruları ve sürece etkisi incelenmiştir. Ele alınan sorular için MYO öğrencilerinin belirsizlik durumlarında limit değerini bulabilmeleri doğrultusunda verdikleri cevaplar ortaya çıkarılmıştır. Aşağıda bu grubun sorularına örnek olarak seçilen öğrenci cevaplarına yer verilmektedir. Genel olarak limit aranan fonksiyonda sonsuzlukla karşılaşan MYO öğrencilerinin fonksiyonda $\left(\frac{\infty}{\infty}\right)$ belirsizliği olduğunu ifade ettikleri görülmüştür. Böyle cevapların ezbere bilgi parçası olduğu söylenebilir. MYO öğrencileri bu sorularda yer alan $\left(\frac{\infty}{\infty}\right)$ belirsizliğinde limitin nasıl bulunacağını düşünmeden yazılımda buldukları limit değerini cevap olarak yeterli bulmuşlardır. Bu sorular ile ilgili Samet ile AÖ arasında geçen diyalog şu şekildedir;

S: Hocam bu çalışma yaprağında fonksiyonun sonsuzluktaki limiti isteniyor. O halde sonsuza gidersek sonuç sonsuz olur.

AÖ: Emin misin Samet?

S: Değilim hocam. Demek ki başka bir şey bulmam gerekiyor. Yoksa burada çözüm yapamadığımız $\left(\frac{\infty}{\infty}\right)$ mu var?

AÖ: Niçin çözüm yapamıyorsun?

S: Şimdi, hocam $x^{\prime}$ in $-\infty$ olduğunu düşünürsem ... x yerine $-\infty$ yazarsam olmaz ki... Onun için çözüm olmaz.

AÖ: Böyle durumlarda ne yapabiliriz? Biraz sesli düşünerek bilgilerini yokla bakalım!

S: Şimdi Derive'de fonksiyonu az önce yazdiğımız gibi yazarız ve limitini bul deriz. Böyle değil mi hocam? İşte limit var ve 2! (Derive yazılımında fonksiyonun $-\infty$ limitini bulur) 


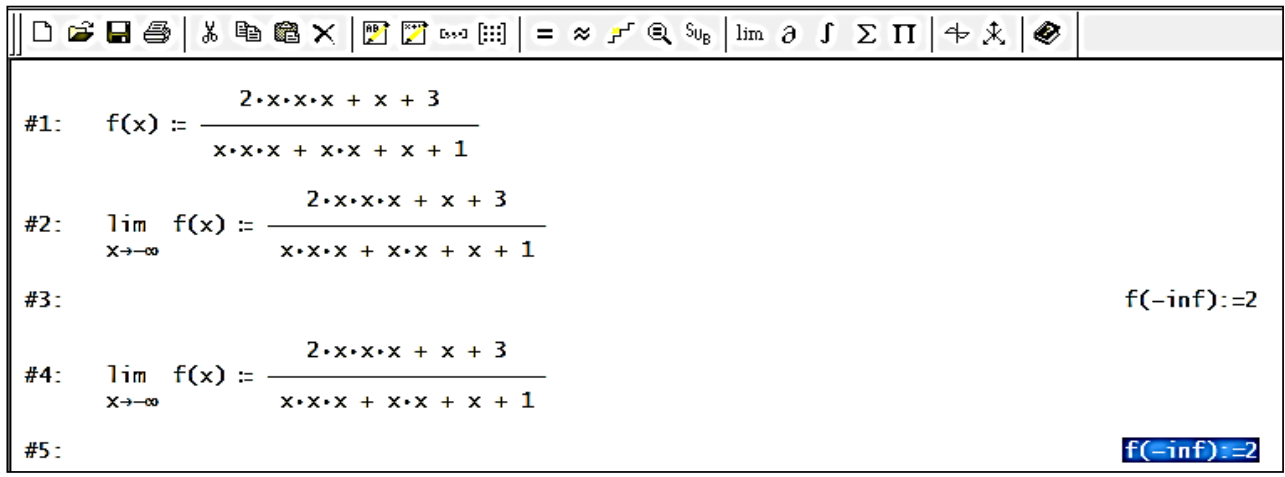

Şekil 2. Samet'in derive yazılımı üzerinde yaptığı işlemler

AÖ: Bu sonuca Derive olmasaydı nasıl ulaşacaktın? Nasıl bir yol izleyecektin?

S: Şimdi - $\infty^{\prime} a$ E kadar yaklaşırız ve belirsizlik buluruz. Sonra Derive'den sonuç 2 çıkar. Böylece limiti bulmuş oluruz. (Samet çalışma yaprağına düşüncelerini yazar)

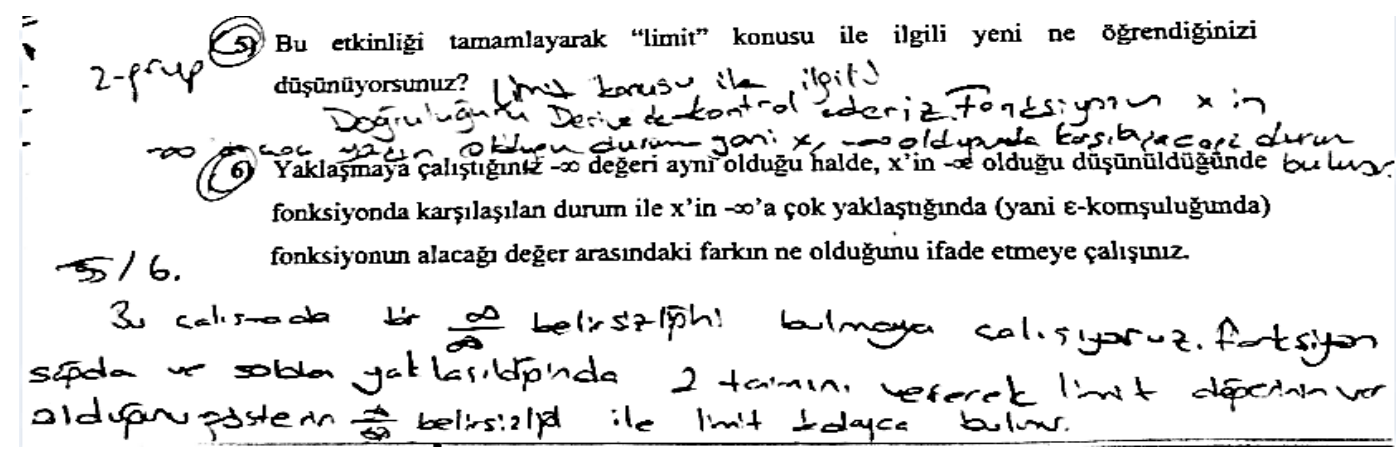

Şekil 3. Samet'in çalışma yaprağı üzerine yazdığı yorumlar

$\left(\frac{\infty}{\infty}\right)$ belirsizliğinde limit değerini bulabilmeyle ilgili cevap beklenen bu soru grubunda, sonsuzluk ifadesiyle karşılaşan Samet limitin $\infty$ olması gerektiğini belirtmiştir. Limit olmasa bile burada mutlaka bir belirsizliğin olduğunu vurgulayan Samet'in cevapları ilk önce TY seviyesinde başlamıştır. Yazılımı kullandıkça $-\infty$ 'da çözüm yapamayacağını belirten Samet'in $\left(\frac{\infty}{\infty}\right)$ belirsizliğine rağmen limitin var olabileceğini söyleyebilmesi cevaplarının bir adım daha geliştiğini göstermektedir. Buna rağmen Derive yazılımı olmadan istenen limiti bulamayan Samet, $\left(\frac{\infty}{\infty}\right)$ belirsizliğinde limitin nasıl hesaplanabileceği hakkında başarılı olamamıştır. Bu ise, elde edilen belirsizlik durumunu ortadan kaldırmadan yazılım desteği ile limitin varlığına ulaşan Samet'in sahip olduğu bilgi parçalarını birleştirmede başarılı olamadığını göstermiştir. Bu açıdan bakıldığında Samet'in cevapları, aralarında ilişki kurulmaksızın birden fazla veriyi içerdiğinden "ÇY" seviyesine yerleştirilmiştir. $\mathrm{Bu}$ soru grubuna verilen bütün öğrenci cevapları incelendiğinde 21 
öğrencinin cevaplarında Samet'in cevaplarına benzer ifadelerle karşılaşılmıştır. Bu ifadeler aşağıdaki şekildedir;

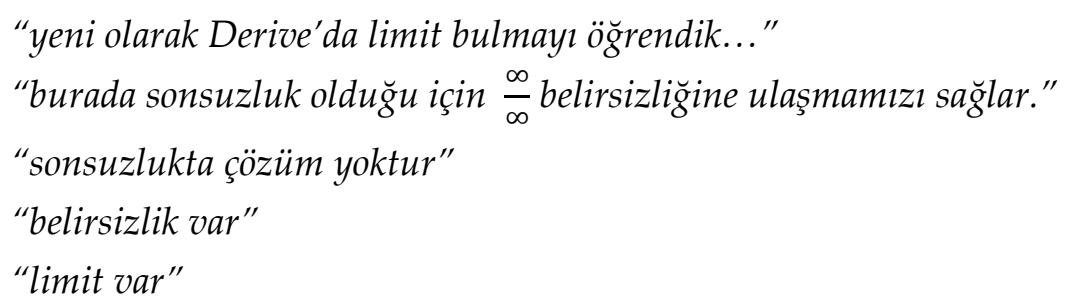

Geri kalan öğrencilerden Hülya, Veysel, Derya, Ferhat, Üzeyir, Nevim, Harun, Ozan ve Resul'ün verdiği cevapların birbirine benzer ve "TY" seviyesinde olduğu görülmüştür. Merve ve Okan'ın verdiği cevapların ise birbirine yakın ve "ÇY+" seviyesinde olduğu görülmüş̧ür. Aşağıda ÇY+ seviyesinde verilen cevaplara örnek olması açısından ders sürecinde Okan ile araştırmacı öğretmen arasında geçen diyaloga yer verilmiştir.

O: $B u$ soru grubunun yer aldı̆̆ı çalışma yaprağında verilen $f(x)=\frac{2 x^{3}+x+3}{x^{3}+x^{2}+x+1}$ fonksiyonunun limitini aramamı istenmişti.

AÖ: Neredeki limiti istenmişti?

$O$ : Hocam $x,-\infty$ 'a sağdan yaklaşırken var olan limiti istenmişti. Bunun için yapılması gereken

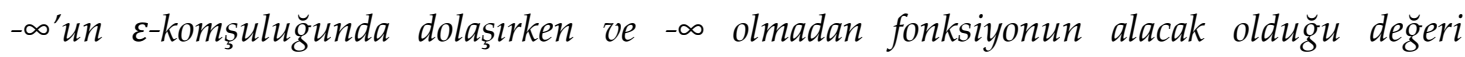
bulmaktır. Bu limit değerini de Derive yazılımı ile bulabiliyorduk. Bu değer 2 olarak karşımıza çıkıyor.

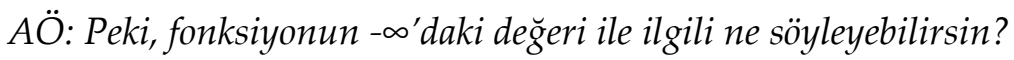

O: İşte burada tıkanıyorum. (Derive yazılımında aşă̆ıda verilen işlemleri yaptıktan sonra)

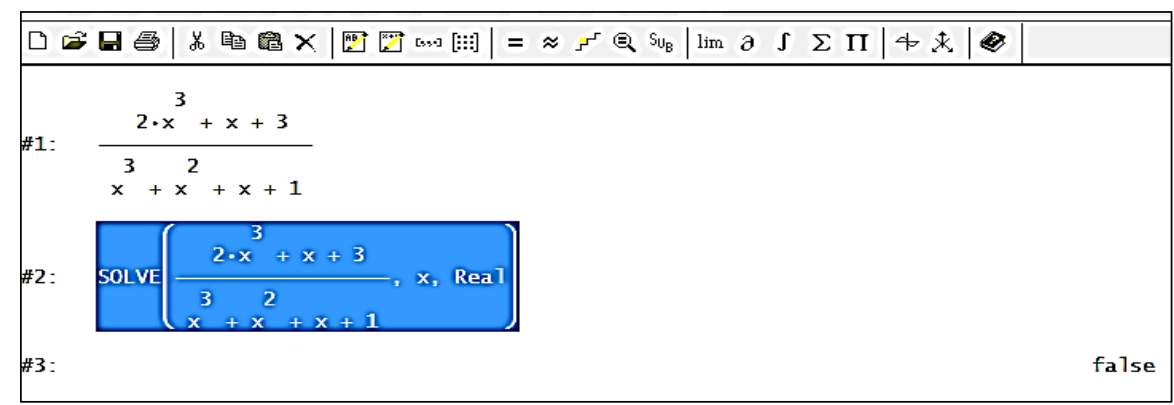

Şekil 4. Okan'ın derive yazılımı üzerinde yaptığı işlemler

O: Burada da belirsizlik var çünkü Derive yine "false" dedi. Bu belirsizlik ise $\frac{\infty}{\infty}$ belirsizliğidir. Zaten bunu daha önceden de bulmuştum. Limit var 2 , belirsizlik var $\frac{\infty}{\infty}$... Şimdi bana limiti nasıl bulduğumu soracaksınız biliyorum! Derive yazılımının haricinde tabî̀ ki de... $\frac{\infty}{\infty}$ belirsizliğinin bir çözüm kuralı vardı... Hatırladı̆̆ım kadarıla x3'lerin katsayısını bölüyorduk işte limit burada budur "2". Bu tip bir şeydi işte hocam... $\frac{\infty}{\infty}$ belirsizliğinde limit var ve bulunabilir. (Söylediklerini çalışma yapră̆ına yazar) 


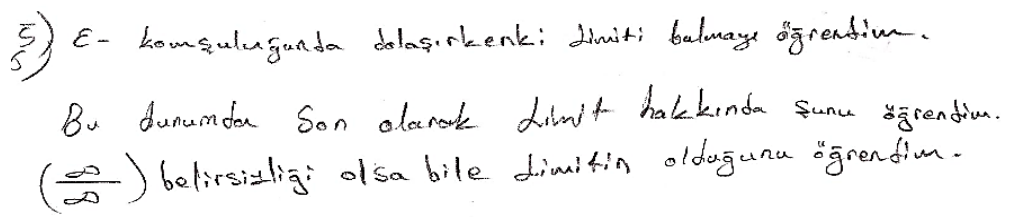

Şekil 5. Okan'ın çalışma yaprağı üzerine yazdığı yorumlar

AÖ: Neden $x^{3}$ 'lerin katsayısını böldün?

O: Hocam çünkü bir şeylerin katsayısını bölme kuralı vardı burada da Derive yazılımı limiti 2 buldu. O halde $x^{3}$ 'lerin katsayısını bölmem gerekir diye düşündüm.

AÖ: Teşekkürler.

Fonksiyonun sonsuzdaki çözümünü yazılım üzerinde yapıp “false" ifadesiyle karşılaşan Okan, soru grubunda $\frac{\infty}{\infty}$ belirsizliği olduğunu söyleyebilmiştir. Ayrıca Okan'ın mantıkla açıkladığı kural ve kuralın doğruluğu dikkat çekicidir. Bu kurala ulaşmasında Derive yazılımının katkısının olması etkileyicidir. Birbiri ile tutarlı cevaplar veren öğrenci, fonksiyonun $\frac{\infty}{\infty}$ belirsizlik durumunda limit değerini hesaplayabilmiştir. Kuralın kavramsal açıklamasını yapmada güçlük çeken Okan'ın cevapları İY’den uzaklaştırmıştır. Bu soru grubuna benzer cevaplar veren Merve'nin cevapları da Okan'ın cevaplarıla kavramsal anlamadan uzak olan fakat birden fazla yöne odaklanılan cevapları içeren "ÇY+" seviyesine yerleştirilmiştir. Bu Soru Grubu içinde yer alan sorulara ders sürecinde verilen cevapların tamamı incelendiğinde 9 öğrencinin cevapları (TY), 21 öğrencinin cevapları (ÇY) ve 2 öğrencinin cevapları ise $(\mathrm{ÇY}+)$ seviyesine yerleştirilebilmiştir. Aşağıdaki tabloda MYO öğrencilerinin fonksiyonun belirsizlik durumlarında limit değerini bulmayı öğrenmelerine yönelik vermiş oldukları cevapların SOLO taksonomisine göre seviyelerinin öğrenci cevap sayısı belirtilmiştir. Bu seviyeler altında verilen öğrenci cevap sayıları o öğrencilerin ulaştıkları en üst seviyeyi göstermektedir. Böylece bu grupta yer alan sorulara verilen cevapların seviyesi genel olarak temsil edilmektedir.

Tablo 3. SOLO seviyesine öğrenci cevap sayısı

\begin{tabular}{|c|c|c|c|c|c|c|c|c|c|c|c|c|c|}
\hline $\begin{array}{l}\text { Soru } \\
\text { Grubunun } \\
\text { Ad1 }\end{array}$ & $\begin{array}{l}\text { Çalışma } \\
\text { Yaprağı }\end{array}$ & $\begin{array}{l}\text { Soru } \\
\text { No }\end{array}$ & SOLO & viyele & & & & & & & & & \\
\hline $\begin{array}{l}\text { Birinci } \\
\text { Soru }\end{array}$ & & & $\begin{array}{ll}- & Y O ̈ \\
& (1) \\
\end{array}$ & + & $\begin{array}{l}\text { TY } \\
(2) \\
\end{array}$ & + & & $\begin{array}{l}\text { ÇY } \\
\text { (3) }\end{array}$ & + & 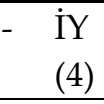 & + & $\begin{array}{l}\text { SY } \\
(5) \\
\end{array}$ & + \\
\hline Grubu & 3 & 5,6 & & & 9 & & & 21 & 2 & & & & \\
\hline
\end{tabular}


Tablo 3 incelendiğinde öğrencilerin bu soru grubunda ele alınan sorulara verdiği cevaplardan toplam 9 (TY, 2), 21 (ÇY, 3) ve 2 (ÇY+, 3.25) seviyesinde öğrenme çıktısı elde edilmiştir. Böylece fonksiyonun tanımsız olduğu noktalarda elde edilen belirsizlik durumlarında limit değerini bulabilme ile ilgili incelenen bu sorularda MYO öğrencilerinin verdikleri cevapların genel olarak (TY, 2) ile (ÇY, 3) seviyelerinde olduğu belirtilebilir. Bu durum MYO öğrencilerinin, belirsiz durumlarda limit bulunabilmesine yönelik sorulan soru gruplarında sorunun tek bir yönüne odaklandığını ve birbirinden kopuk bilgi parçalarını birbiriyle tutarlı şekilde ilişkilendirmede başarılı olamadığını ortaya çıkarmaktadır. Tablo 3'te verilen veriler ve bu verilere ait veri analizleri incelenerek MYO öğrencilerinin bu soru grubuna verdikleri cevapların ortalama seviyesi belirlenmiştir. Ortaya konan bu ortalama seviye ilgili başlık altındaki her soruya bu seviyede cevap verileceği anlamına gelmese de genel bir bakış açısı sunmaktadır. Bu doğrultuda diğer başlıklar arasında kıyas yapabilmeyi kolaylaştırmak ve genel bir bakış sunmak açısından öğrenci sayıları doğrultusunda SOLO seviyelerine karşılık gelen cevapların ortalama puanlaması aşağıdaki grafik ile özetlenmiştir.

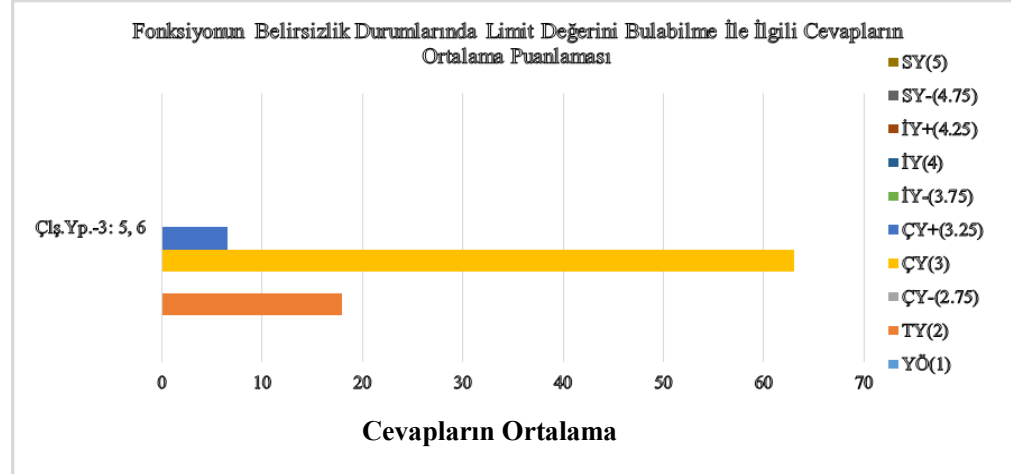

Grafik 1. Solo seviyelerine karşılık gelen cevapların ortalama puanlaması

Grafik 1, fonksiyonun belirsizlik durumlarında limit değerini bulabilme ile sorulara verilen cevaplardan 9'unun TY seviyesinde olmasının ortalama 18 (TY), 21'inin ÇY seviyesinde olmasının ortalama 63 (ÇY), 2'sinin ÇY+ seviyesinde olmasının ortalama 6.5 (ÇY+) puanlamasına karşılık geldiğini göstermektedir. Yukarıda bu grubu özetlemek için verilen tablo, grafik ve diyaloglar süreçler halinde incelendiğinde, yazılımı kullanmaya başlamadan önce kâğıt-kaleme yönelen öğrencilerin, soruların bir yönüne odaklanan cevaplar verdiği, yazılımın kullanılmasıyla verilen cevapların geliştiği ve birbirinden bağımsız anlamlı bilgi parçalarını içerdiği görülmüştür. Ayrıca yeni dönem ders sürecinde öğrenciler çalışma yapraklarındaki soruları çözmek için doğrudan yazılıma yönelmiştir. Derive yazılımı olmadan limit bulmakta güçlük çeken öğrencilerin yazılıma yönelmeleri öğrenme sürecinde teknolojiye olan eğilimin arttığını göstermektedir. 
Fonksiyonun Grafiğini İnceleyip Sürekli Olduğu Aralıkları Bulabilme ile İlgili Bulgular

Bu başlık altında İkinci Soru Grubu kapsamında ele alınan 5. çalışma yaprağının 6., 7. soruları ve sürece etkisi incelenmiştir. Ele alınan sorular için MYO öğrencilerinin fonksiyonun grafiğini inceleyip sürekli olduğu aralıkları bulabilmeleri doğrultusunda verdikleri cevaplar ortaya çıkarılmıştır. Aşağıda bu grubun sorularına örnek olarak seçilen öğrenci cevaplarına yer verilmektedir.

Genel olarak MYO öğrencilerinin verilen fonksiyonun grafiğini Derive yazılımında yer alan grafik çizme menüsü $\{$. yardımıyla çizmekte zorluk çekmediği görülmüştür. Ayrıca bu sorularda yer alan fonksiyon grafiğinin $x=0$ noktasında yoğunlaşmış olması $\mathrm{MYO}$ öğrencilerinin merakını arttırmıştır. Bu sorular ile ilgili Özcan ile AÖ arasında geçen diyalog aşağıdaki gibidir;

Ö: Hocam bu karışık fonksiyonun grafiğini inanın ki çok merak ediyorum.

AÖ: Neden?

Ö: Aslında şu ana kadar grafik çizimi ile ilgili hiçbir bilgi sahibi olmayan biri olarak bütün fonksiyonların grafiğini merak ediyorum. Fakat bu sorulardaki fonksiyonun $\infty .0$ gibi dikkat çekici bir belirsizliği vardı... Belki de ondan bu grafiği daha çok merak etmişimdir.(Bu süreçte Derive yazılımı yardımıyla aşağıda verildiği gibi fonksiyonun grafiğini çizen Özcan, grafik üzerinde hareket ederek istenen $\infty^{\prime} l u \breve{g} a$ yaklaşmaya çalışırken çalışma yapră̆̆ üzerine yazdı̆̆ yorumlara yer verir)
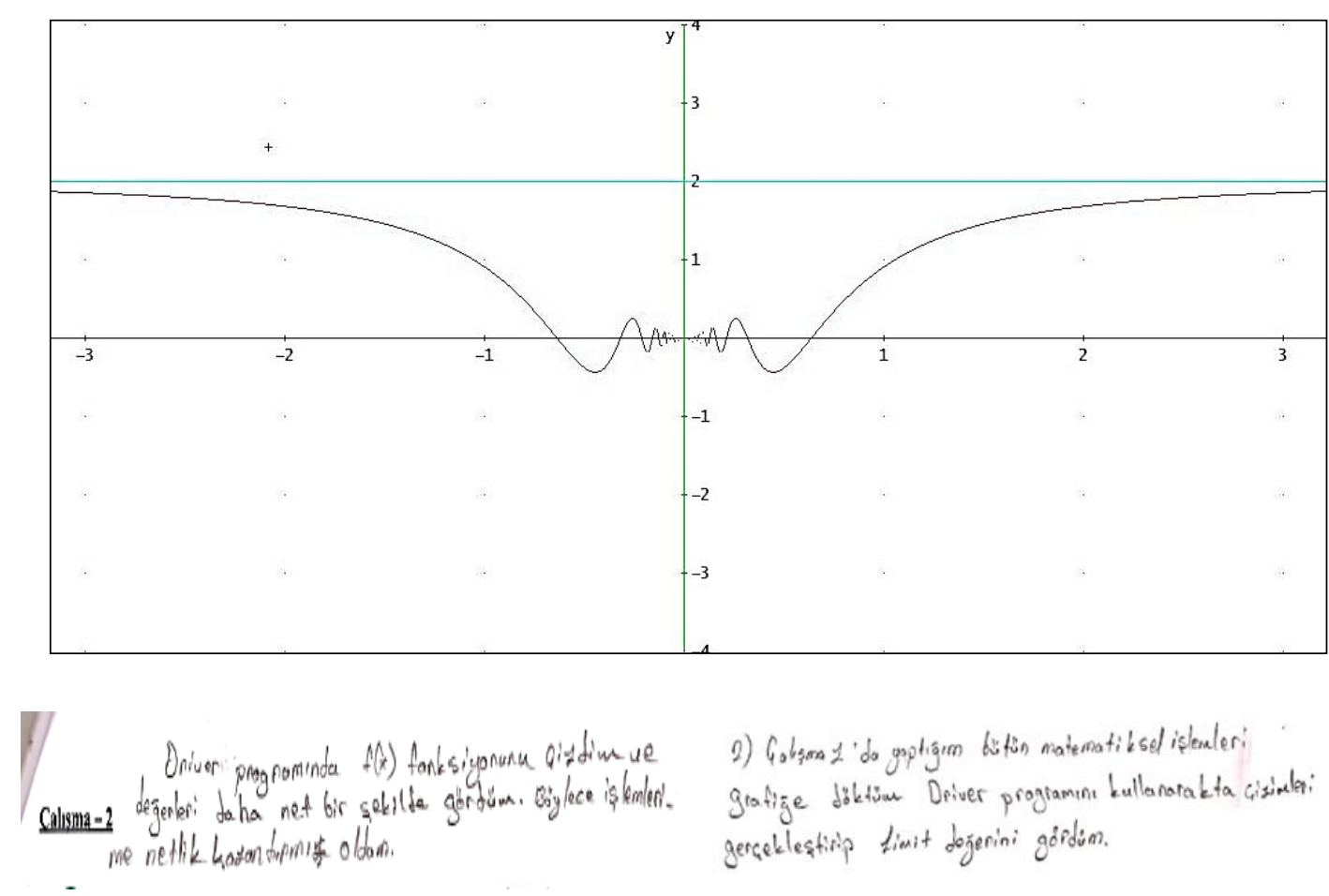

Şekil 6. Özcan'ın derive yazılımı üzerinde yaptığı çizimler ve çalışma yaprağına yazdığı yorumlar 
Ö: Bakın hocam şu anda $x, \infty^{\prime} a$ yaklaşırken limit durumunu görmek için zorlanıyoruz. Fakat ben ne yaptım limit noktasının grafiğini de ayn grafik üzerinde çizerek limit değerinin gerçekten de 2 olduğunu bulabildim... Yaptıklarım doğru di mi hocam? (Özcan verdiğ $i$ cevaplar ve çizdiği grafikler sayesinde kendinden emin bir şekilde doğruluğunun onaylanmasın bekliyordu)

AÖ: Evet Özcan, bunlar doğru adımlar.

Ö: Hocam bu grafik çizme menüsü harika bir şey burada sıfir (0)'ın bulunduğu nokta aynen kalp atışları gibi... Insanın dikkatini çekiyor...

AÖ: İstersen o noktayı inceleyebilirsin. Tabî̀ ki bunu yaparken yorumlarım sesli yapacaksın!

Ö: Hocam şimdi grafik üzerinde hareket ederek sifir (0) noktasına yaklaşalım. Aslında bu noktaya sağdan ve soldan yaklaşırken fonksiyonun alacak olduğu değer ayn gibi gözüküyor... (Bu süreçte Özcan grafik üzerinde hareket ederek sifır değerine küçük ve büyük değerlerden yaklaşıyordu. Ayrıca grafik menünsün altında yer alan değerleri de sesli bir şekilde okuyordu) ...vee sifir!!! Hocam burada da limit değeri sifir oluyor galiba!

AÖ: Derive yazılımında bunu gösterebilirsin. O zaman bana sormak zorunda kalmazsin.

Ö: O halde bu fonksiyonun $x$ sıfira yaklaşırken aldığ limit değerini mi bulmam gerek? (Özcan bu süreçte araştırmacı öğretmenin kafa işaretiyle onayını aldıktan sonra Derive yazılımında aşağıdaki işlemleri yaptı)

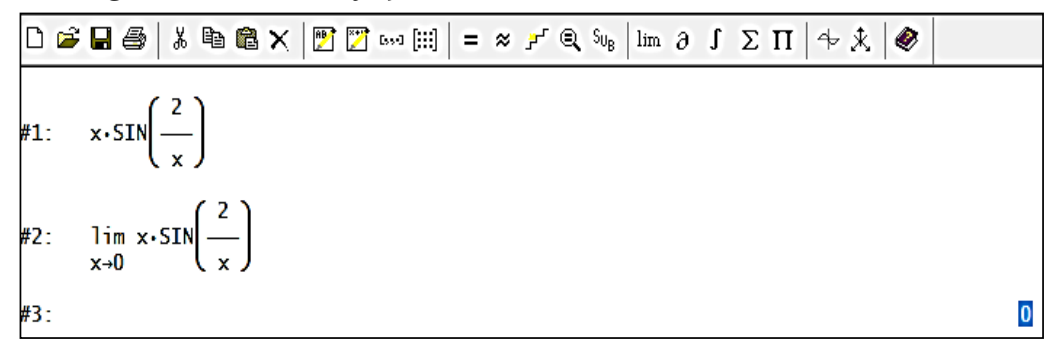

Şekil 7. Özcan'ın derive yazılımı üzerinde yaptığı işlemler

Ö: İşte hocam buldum! Ben buldum! Sıfır grafiği incelerken söylediğ̈im gibi... Çok mutluyum. Bu grafik sayesinde anlattığınız sürekliliği bile inceleyebilirim.

AÖ: O halde bu fonksiyonun grafiğini inceleyerek nerelerde sürekli olabileceğgi hakkında biraz bilgi verebilir misin?

Ö: Hocam! Söylediğim her şeyi bana soru olarak soruyorsunuz! Fakat bu sefer bunu kendim bulacă̆ım. Bir defa süreklilik için fonksiyonun grafiğinde boşluk olmaması gerekmektedir. Bu grafiği incelediğimde sıfıra yaklaşıncaya kadar problem yok gibi gözüküuyor fakat sıfıra çok yaklaştıkça tam olarak bir yorum yapamıyorum... Bu noktanın (sıfırın) çevresi biraz karışık! Neyse en azından sıfırın çevresinin dışında sürekli olduğunu söyleyebilirim. Bütün bunları Derive sayesinde söyleyebiliyorum!

AÖ: Teşekkürler, Özcan.

Özcan'ın verdiği cevaplar incelendiğinde fonksiyonun grafiğini çizmede problem yaşamadığını görmekteyiz. Ayrıca fonksiyonun grafiğine limite ait grafiği ilave etmesi önceki aşamaların doğrulanması açısından çok önemlidir. Grafikte sıfır noktası ilgi çekici bir nokta olduğundan bu noktayı incelemek isteyen Özcan, süreklilik hakkında bilgi vermekte 
başarılı olmuştur. Böylece grafik üzerinde süreklilik ararken fonksiyonun kopuk olmaması gerektiğini vurgulayan Özcan, sıfır noktası ile ilgili net bilgi verememesine rağmen bu noktanın dışında fonksiyonun sürekli olduğunu belirtmiştir. Özcan’a göre Derive yazılımı kâğıt üzerinde gösteremediği grafiklerin çizimi için mükemmel bir ortamdı ve grafik üzerinde hareket etmek O'nun için dikkatini çeken her noktayı inceleyebilmesine olanak sunuyordu. Böylece Özan'ın cevapları soru grubuna ilişkin birden fazla özelliği içerip kavramsal anlamayı içerdiğinden "IYY" seviyesi içerisinde sınıflandırılmıştır.

$\mathrm{Bu}$ soru grubuna verilen cevapların tamamı incelendiğinde Merve, Okan, Fatma ve Devrim'in cevaplarında da Özcan'ın ifadelerine benzer ifadelerle karşılaşılmıştır. Geri kalan öğrenciler limit-süreklilik için fonksiyon grafiğinin gerekli olduğunu farkında olup bulmuş olduğu grafiği yorumlamada güçlük çekmişlerdir. Bu öğrenci cevapları incelendiğinde sorulan sorularla ilişkili fakat birbirinden kopuk bilgi parçalarını içerdiği görüldüğünden "ÇY" seviyesine yerleştirilmiştir. Aşağıda ÇY seviyesinde verilen cevaplara örnek olması açısından Seher ile AÖ arasında geçen diyaloğa yer verilmiştir

S: Hocam şimdi Derive'de $f(x):=x \cdot \sin \frac{2}{x}$ fonksiyonunun grafiğini çizelim. (Seher bu süreçte Derive yazılımında önceki adımlarda yapmış olduğu işlemlerden fonksiyonu işaretleyip grafik çizimini aşă̆ıdaki gibi yapmıştır.)

\#\#2: $\lim _{x \rightarrow \infty} f(x):=x \cdot \operatorname{SIN}\left(\frac{2}{x}\right)$

Şekil 8. Seher'in derive yazılımı üzerinde yaptığı işlemler

S: Hocam bu ne kadar güzel bir grafik! Çok beğendim. Şimdi ne yapmam gerekiyor?

AÖ: Az önce yapmış olduğun çözümleri burada göstermen isteniyor.

S: Evet az önce sonsuzda limit bulmuştuk. Grafik üzerinde sonsuz! Şimdi limit 2'dir. 2 burada! Grafik düzgün gidiyor. Oysa merkeze doğru kalp atışı gibi çizgiler var. Burası sıfır noktası! Hocam grafik düzgün giderken sıfıra doğru yoğunlaşma var.

AÖ: Peki bu yoğunlaşmayı inceleyebilir misin? Ayrıca bu grafikte süreklilik hakkında ne söyleyebilirsin? 
S: Şimdi grafik sonsuza kadar gidiyor. Düzgün bir grafik ve sıfır noktasında yoğunlaşıyor. Sonsuza kadar düzgün gittiği için sürekli mi oluyor? Fakat bu fonksiyonda belirsizlik vardı! Ya hocam ben tam anlayamadım galiba! Sürekli mi? Limit var 2. (Seher söylediklerinden emin olmadan araştırmacı öğretmenin onayını bekliyordu. Bu süreçte çalışma yapră̆ına yazmış olduğu cevaplar aşağıldaki gibidir)

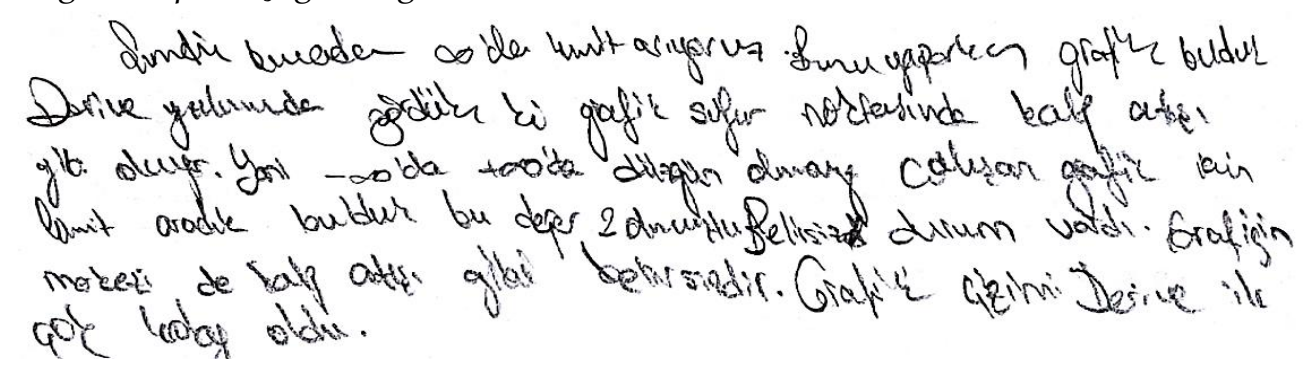

Şekil 9. Seher'in çalışma yaprağı üzerine yazdığı yorumlar

Seher'in bu soru grubu ile ilgili çalışmaları ve yorumları incelendiğinde çalışma boyunca kendinden emin olmadı̆̆ı görülmüştür. Oysa grafik çizimi yapabilen Seher çalışma yaprağında yapmış olduğu önceki adımlar sayesinde belirsiz bir durumun olduğunu ve burada limitin ne olması gerektiğini biliyordu. Buna rağmen Seher'in verdiği cevaplarda grafik üzerinde $\infty^{\prime}$ a yaklaşırken limit durumunu gösterememiş olması ve grafiğin sıfır noktasına dikkat çekmesi birbirinden kopuk bilgi parçalarını içerdiğinden "ÇY" seviyesine yerleştirilmiştir. Öğrencilerin genel olarak (27 öğrenci) Seher'in cevaplarına benzer cevaplar verdiği görülmüştür. Ayrıca TY seviyesinde başlayan bazı cevapların ise sorulan sorular, grafik incelemeleri ve diyaloglar sonucu ÇY ve İY seviyesine yerleştirilebilecek düzeye çıktığı görülmüştür.

$\mathrm{Bu}$ soru grubu içinde yer alan sorulara verilen cevapların tamamı incelendiğinde 5 öğrencinin cevapları (IY) seviyesine, geri kalan 27 öğrenci cevabı ise (ÇY) seviyesine yerleştirilebilmiştir. Aşağıdaki tabloda MYO öğrencilerinin fonksiyonun grafiğini inceleyip sürekli olduğu aralıkları bulmayı öğrenmelerine yönelik vermiş oldukları cevapların SOLO taksonomisine göre seviyelerinin öğrenci cevap sayısı belirtilmiştir.

Tablo 4. SOLO seviyesine göre öğrenci cevap sayısı

\begin{tabular}{|c|c|c|c|c|c|c|c|c|c|c|c|c|c|}
\hline $\begin{array}{l}\text { Soru } \\
\text { Grubunun } \\
\text { Adi }\end{array}$ & $\begin{array}{l}\text { Çalışma } \\
\text { Yaprağı }\end{array}$ & $\begin{array}{l}\text { Soru } \\
\text { No }\end{array}$ & SOLO & viyel & & & & & & & & & \\
\hline \multirow{2}{*}{$\begin{array}{l}\text { İkinci Soru } \\
\text { Grubu }\end{array}$} & & & 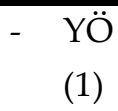 & + & $\begin{array}{l}\mathrm{TY} \\
(2)\end{array}$ & + & & $\begin{array}{l}\text { ÇY } \\
\text { (3) }\end{array}$ & + & $\begin{array}{rr}- & \dot{I} Y \\
& (4)\end{array}$ & + & $\begin{array}{r}\text { SY } \\
(5)\end{array}$ & + \\
\hline & 5 & 6,7 & & & & & & 27 & & 5 & & & \\
\hline
\end{tabular}

Tablo 4 incelendiğinde öğrencilerin bu soru grubuna verdiği cevaplardan toplam 27 (ÇY,3); 5 (İY, 4) seviyesi nde öğrenme çıktısı elde edilmiştir. Böylece fonksiyonun grafiğini 
inceleyip sürekli olduğu aralıkları bulabilme ile ilgili incelenen bu sorularda, MYO öğrencilerinin verdikleri cevapların genel olarak $(C ̧ Y, 3)$ ile (İY,4) seviyeleri arasında olduğu belirtilebilir. $\mathrm{Bu}$ durum MYO öğrencilerinin, grafik üzerinde limit-süreklilik inceleyebilmelerine yönelik sorulan soru gruplarında bilgi parçalarını tüm yönleriyle ilişkilendirmede başarılı olamasalar da tutarlı ifadeler kullandıklarını ortaya çıkarmaktadır.

Tablo 4'te verilen veriler ve bu verilere ait veri analizleri incelenerek MYO öğrencilerinin bu soru grubuna verdikleri cevapların ortalama seviyesi belirlenmiştir. Bu doğrultuda diğer başlıklar arasında kıyas yapabilmeyi kolaylaştırmak ve genel bir bakış sunmak açısından öğrenci sayıları doğrultusunda SOLO seviyelerine karşılık gelen cevapların ortalama puanlaması aşağıdaki grafik ile özetlenmiştir.

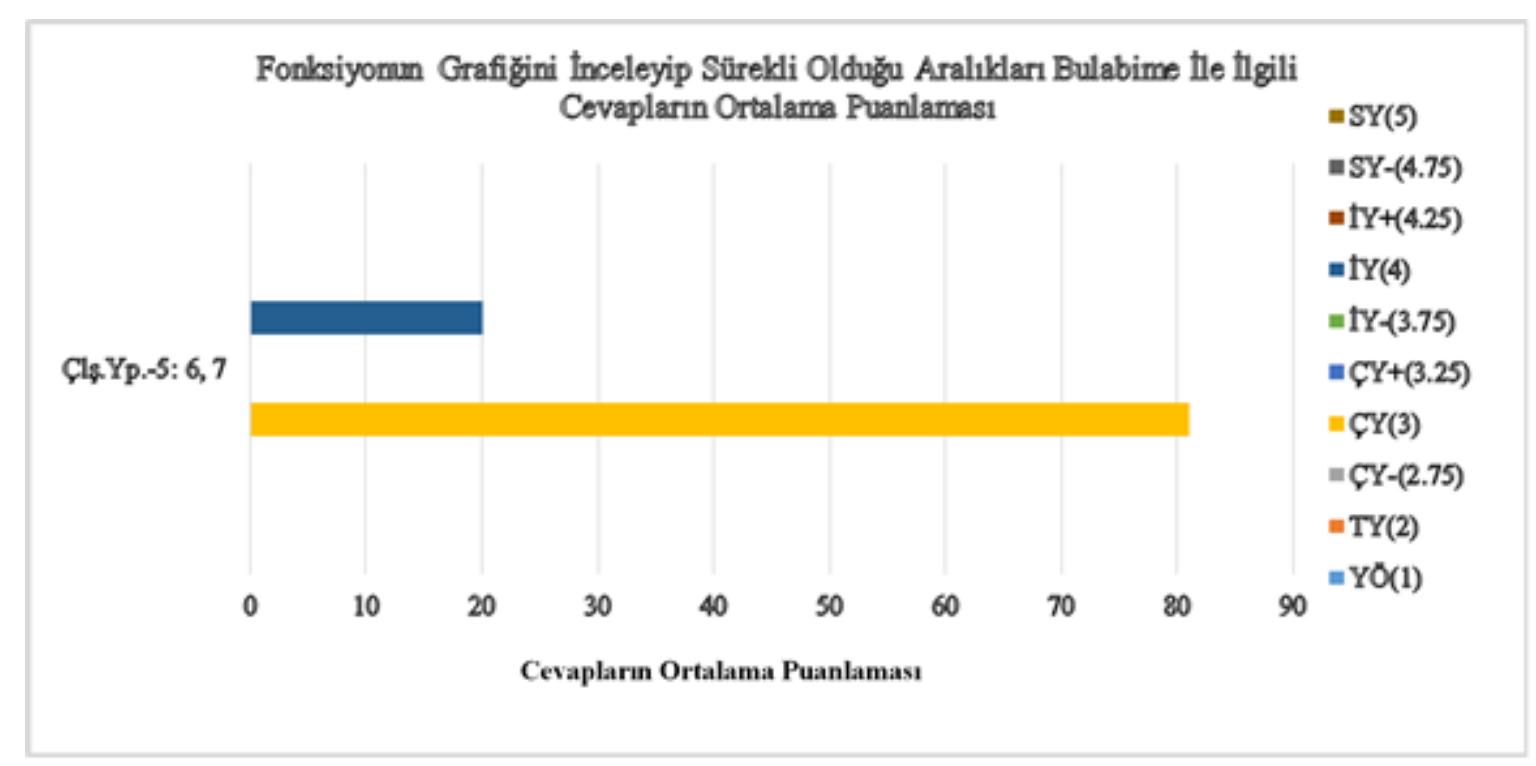

Grafik 2. Solo seviyelerine karşılık gelen cevapların ortalama puanlaması

Grafik 2, fonksiyonun grafiğini inceleyip sürekli olduğu aralıkları bulabilme ile ilgili sorulara verilen cevaplardan 27'sinin ÇY seviyesinde olmasının ortalama 81 (ÇY), 5'inin İY seviyesinde olmasının ortalama 20 (İY) puanlamasına karşılık geldiğini göstermektedir.

Yukarıda bu grubu özetlemek için verilen tablo, grafik ve diyaloglar incelendiğinde, öğrencilerin birbirinden bağımsız bilgi parçaları içeren cevaplarının yazılımın kullanılmasıyla geliştiği, cevaba ilişkin bazı yönlerin birbiriyle olan ilişkilerinin ifade edildiği ve bütün içindeki yerine değinildiği görülmüştür. Yeni dönem ders sürecinde öğrencilerin Derive yazılımı üzerinde fonksiyonun grafiğini bulmaya yönelmesi ve sürekliliği daha anlamlı incelemesi, BCS'nin öğrenme sürecinde öğrencilerin soyut düşünmelerine katkı sağladığını göstermektedir. 
Limit ile Süreklilik Arasında İlişki Kurabilme ile İlgili Bulgular

Bu başlık altında Üçüncü Soru Grubu kapsamında ele alınan 10. çalışma yaprağının 2., 3. soruları ve sürece etkisi incelenmiştir. Aşağıda bu grubun sorularına örnek olarak seçilen öğrenci cevaplarına yer verilmektedir.

Grafiğini çizmiş oldukları $f(x):=\frac{1}{(x-2)^{2}}$ fonksiyonunun $x=2$ noktasını limitsüreklilikle ilişkilendirip incelemeleri istenen bu soru grubunda MYO öğrencileri teorik olarak ifade edemese de limitin olmadığı yerde sürekliliğin olmayacağının farkına varmıştır. Bu sorular ile ilgili İsmail ve AÖ arasında geçen diyalog aşağıdaki gibidir;

I: Şimdi bu fonksiyonun $x=2$ noktasında alacak olduğu değeri incelemek için Derive yazılımını kullandiğımızda... İşte yine "false" bunu önceki çalışmalarda da elde etmiştik. (Derive yazılımı üzerinde fonksiyonun $x=2$ için çözümünü yaptığında aşă̆ıdaki sonuçları elde eder)

\begin{tabular}{|c|c|c|c|}
\hline 成昌昌 & 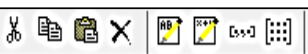 & 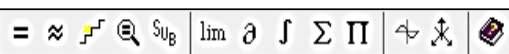 & \\
\hline & 1 & & \\
\hline & $x \cdot x-4 \cdot x+4$ & & \\
\hline & 1 & & \\
\hline \#2: NSOLVE & $\overline{x \cdot x-4 \cdot x+4}, x, 2,2$ & & \\
\hline \#3: & & & false \\
\hline
\end{tabular}

Şekil 10. İsmail'in Derive Yazılımı Üzerinde Yaptı̆̆ İşlemler

AÖ: Bu durumda ne dememiz gerekir?

İ: Tabî ki tanımsız bir fonksiyondur dememiz gerekir... Yani verilen noktada tanımsızdır diyorduk... Şimdi bu nokta için limit ve süreklilik yoktur diyebilir miyim?

AÖ: Emin misin İsmail? İstersen yazılımı tekrar kullan! Belki fikrin değişir. (İsmail fonksiyonun $x=2$ noktasında limitini bulmak için Derive yazılımında yaptı̆̆g işlemlere aşağ̆ldaki gibi devam etmiştir)

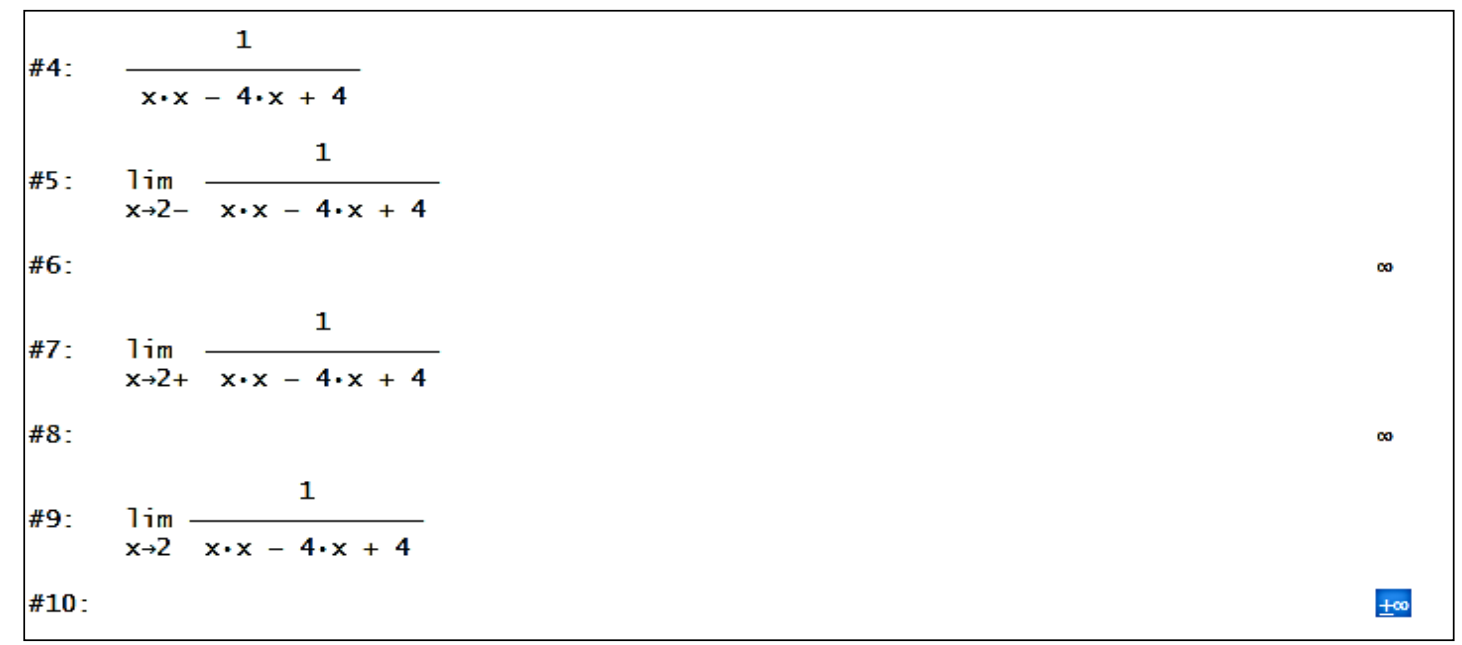

Şekil 11. İsmail'in derive yazılımı üzerinde yaptığı işlemlerin devamı 
I: Özür dilerim hocam! Süreklilikle karıştırdım. Limit varmış... Ayrıca bu limit değeri "s" muş. (İsmail'in çalışma yapră̆ına yazdığı yorumlar aşă̆ıdaki gibidir)

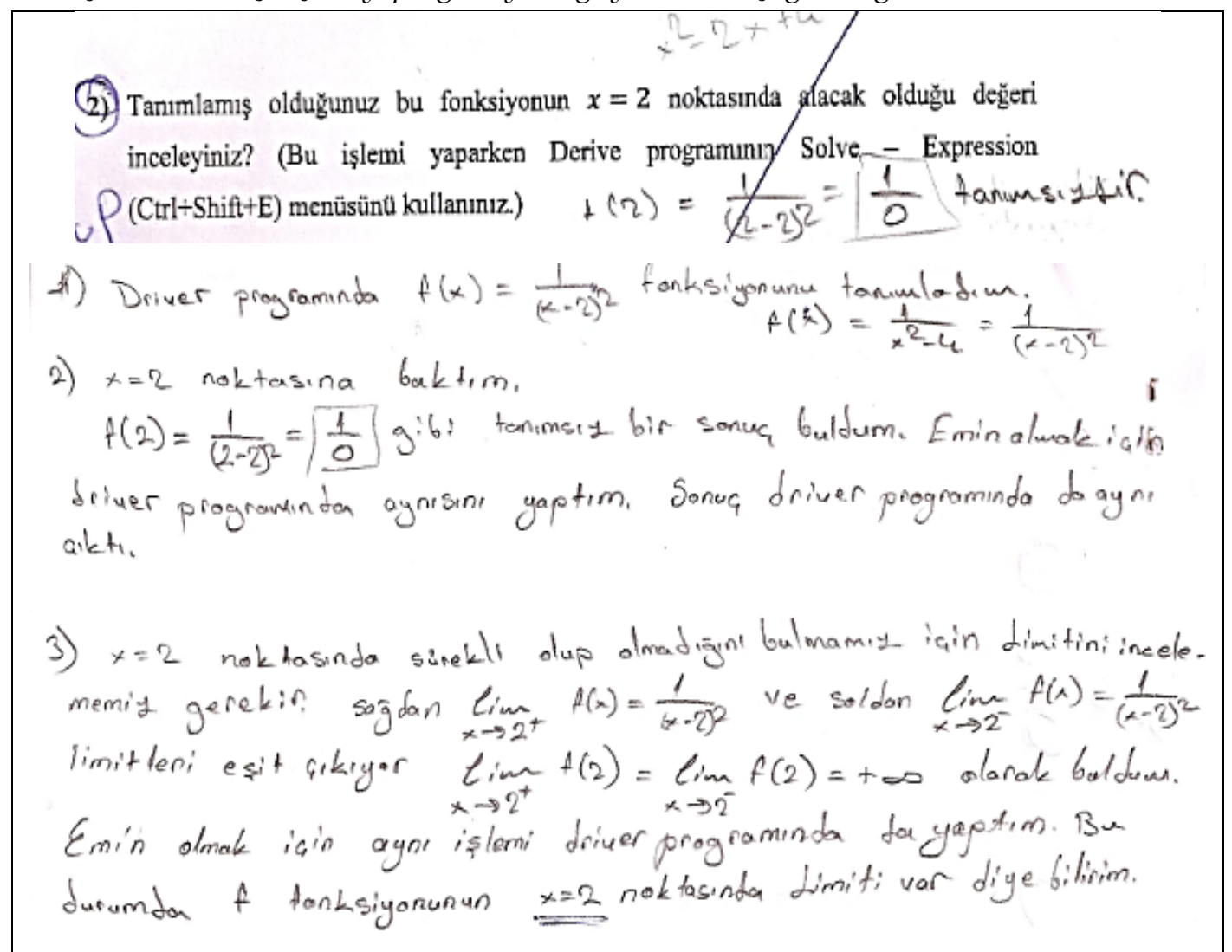

Şekil 12. İsmail'in çalışma yaprağı üzerine yazdığı yorumlar

AÖ: Şimdi sürekliliğini incelemeye çalış bakalım.

I: Hocam bu soruda fonksiyonun verilen noktada limitinin olduğunu bulabildim fakat grafik çizimi olmadı̆̆ından sürekli olup olmadığı hakkında kesin bir yargıya varamıyorum... Fonksiyon verilen noktada $\frac{1}{0}$ olduğu için tanımsızdır bunu da bulabiliyorum. Keşke sürekli olduğunu bilsem limit vardır diyebilirdim fakat limitin varlığından sürekliliğ i inceleyebileceğimi zannetmiyorum. Herhalde grafik olmadan süreklilĭgi bulamam... Grafik olunca hem limiti hem de sürekliliği daha kolay inceleyebilirdim.

AÖ: Teşekkürler, İsmail!

İsmail'in verdiği cevaplar incelendiğinde $\mathrm{x}=2$ noktasını fonksiyonda yerine yazarak elde ettiği $\frac{1}{0}$ ifadesinin bir tanımsızlık olduğunu belirtmekte başarılı olduğu görülmektedir. Fakat $x=2$ değerinde limit değerini bulmasına rağmen grafik çizimi olmadan süreklilik hakkında bilgi vermekte başarılı olamamıştır. Bu durum İsmail'in limit-süreklilik arasındaki ilişki ile ilgili vermiş olduğu cevapların grafiğe bağlı, ezbere ve belli sınırlar içerisinde kaldığını göstermektedir. Bütün ifadeleri göz önünde bulundurulduğunda İsmal'in cevapları "ÇY+" seviyesine yerleştirilmiştir. Beklenen öğrenmeyi gerçekleştiremese de limit olmadan 
sürekliliğin olmayacağını ifade eden ve İsmail'in cevaplarına benzer ifadeler içeren 23 öğrenci cevabı "ÇY+" seviyesine yerleştirilmiştir.

Fonksiyonun $x=2$ için tanımsız olduğunu farkına varan öğrencilerden 8 'i ettiği $\frac{1}{0}$ tanımsızlı̆̆ına odaklanmıştır. Grafik çizimi olmadan sürekliliği inceleyemeyeceklerini belirten bu 8 öğrenci "limit ve süreklilik birbirinden ayrılmaz ikisi birlikte incelenmelidir" gibi kopuk ezbere bilgi parçaları içeren cevaplar verdiğinden bu ifadeler "ÇY-" seviyesine yerleştirilmiştir. Aşağıda (ÇY-) seviyesinde cevap veren 8 öğrenciden seçilen bazı ifadelere yer verilmiştir;

" $f(x):=\frac{1}{(x-2)^{2}}$ fonksiyonunun $x=2$ noktasında aldı̆̆ değgeri bulmak için $x$ yerine 2 yazarız. Paydası sıfır olur burada tanımsızlık vardır. Şimdi Derive de limit buluruz" (önceki çalışma yapraklarında yapılan işlemler ezberlenmiş)

"burada $x=2$ noktasın incelememiz ve süreklilikle ilişkilendirmemiz istenmiş. Grafiğini çizmeden sürekliliği inceleyemeyiz. Fakat limitini bulabiliriz. Grafikte noktaya yaklaşmak limittir."

"limit ve süreklilik birbirinden ayrılamaz birbirini tamamlar" (öğrenci fonksiyonun grafiğini yazılım üzerinde çizer ve hiçbir nokta incelemez cevapları ezberedir)

" $x=2$ noktasında limit var çözüm yapınca false çıkıyor" (limit-süreklilik arası ilişki sorulduğunda "biri varsa diğeri vardır" cevabını verir)

Ozan, Adem ve Hülya bu gruba ait önceki çalışma sorularını dikkate almadan fonksiyonda x gördükleri yere 2 yazmakla yetinmişlerdir. Bu 3 öğrenci cevabı, sorunun tek yönüne odaklanan ifadeler içerdiğinden "TY" seviyesine yerleştirilmiştir. Aşağıda (TY) seviyesinde cevap veren bu 3 öğrenciden seçilen bazı ifadelere yer verilmiştir;

"Fonksiyonunun çözümü yoktur false geliyor. Bu gibi fonksiyonlar sorunludur fakat limitini bulunca limit de sonsuz..."

"limit-süreklilik kardeş gibidir" (limit-süreklilik arası ilişki sorulunca öğrencinin verdiği cevaptır)

"limiti hemen buluruz süreklilik için grafik gerek" (limit-süreklilik arası ilişki sorulduğunda öğrencinin verdiği cevap)

$\mathrm{Bu}$ Soru Grubu içinde yer alan sorulara verilen cevapların tamamı incelendiğinde 3 öğrenci cevabı (TY), 8 öğrenci cevabı (ÇY-) ve 21 öğrenci cevabı ise (ÇY+) seviyesine yerleştirilmiştir. Aşağıdaki tabloda MYO öğrencilerinin limit-süreklilik arasında ilişki kurabilmeyi öğrenmelerine yönelik vermiş oldukları cevapların SOLO taksonomisine göre seviyelerinin öğrenci cevap sayısı belirtilmiştir. 
Tablo 5. SOLO seviyesine göre öğrenci cevap sayısı

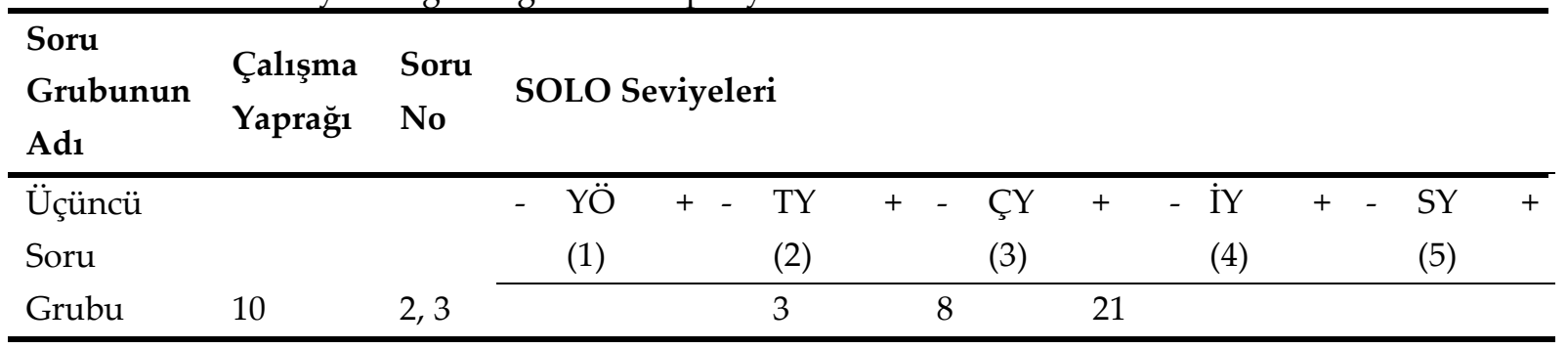

Tablo 5 incelendiğinde öğrencilerin bu soru grubunda ele alınan sorulara verdiği cevaplardan toplam 3 (TY,2); 8 (ÇY-,2.75); 21 (ÇY+, 3.25) seviyesinde öğrenme çıtısı elde edilmiştir. Böylece limit-süreklilik arasında ilişki kurabilme ile ilgili incelenen bu sorularda, MYO öğrencilerinin verdikleri cevapların genel olarak çok yönlü yapı $(C ̧ Y, 3)$ seviyesi çevresinde yoğunlaştı̆̆ı söylenebilir. Tablo 5 te verilen veriler ve bu verilere ait veri analizleri incelenerek MYO öğrencilerinin bu soru grubuna verdikleri cevapların ortalama seviyesi belirlenmiştir. $\mathrm{Bu}$ doğrultuda diğer başlıklar arasında kıyas yapabilmeyi kolaylaştırmak ve genel bir bakış sunmak açısından öğrenci sayıları doğrultusunda SOLO seviyelerine karşılık gelen cevapların ortalama puanlaması aşağıdaki grafik ile özetlenmiştir.

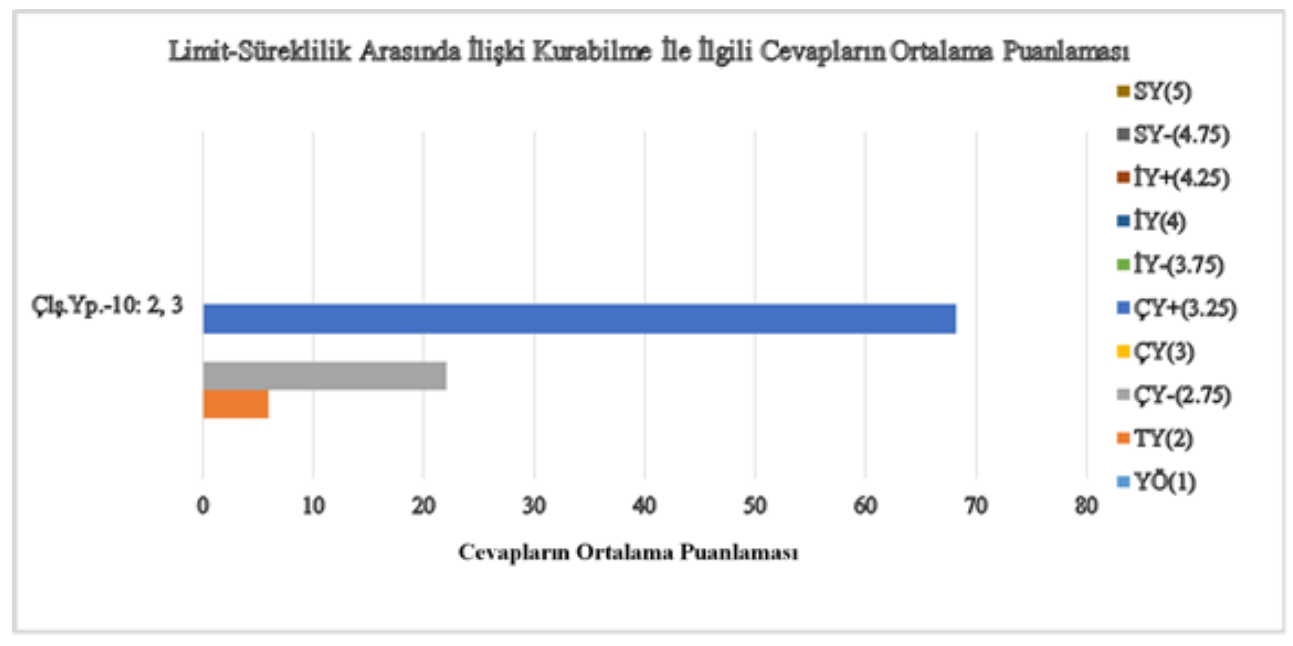

Grafik 3. SOLO seviyelerine karşılık gelen cevapların ortalama puanlaması

Grafik 3, limit ile süreklilik arasında ilişki kurma ile ilgili sorulara verilen cevaplardan 3'ünün TY seviyesinde olmasının ortalama 6 (TY), 8'inin ÇY- seviyesinde olmasının ortalama 22 (ÇY-) ve 21'inin ÇY+ seviyesinde olmasının ortalama 68.25 (ÇY+) puanlamasına karşılık geldiğini göstermektedir. Yukarıda bu grubu özetlemek için verilen tablo, grafik ve diyaloglar incelendiğinde, başlangıçta TY düşünme seviyesinde verilen öğrenci cevaplarının bilgisayar destekli öğrenme ortamında ÇY ve üzeri düşünme seviyesine geliştiğini göstermektedir. Ayrıca yeni dönem ders sürecinde öğrencilerin soruları çözmek için doğrudan yazılıma yöneldiği gözlemlenmiştir. 


\section{Tartışma ve Sonuç}

Genel olarak BCS yazılımının kullanıldığı ortamda MYO öğrencilerinin limitsüreklilik konusu ile ilgili öğrenme çıktıları SOLO taksonomisine göre İY seviyesinin altında olarak değerlendirilmiştir. Ayrıca BCS yazılımı kullanımı, MYO öğrencilerinin YÖ ve TY seviyesindeki öğrenme çıktılarının niteliğinin ve yapısının SY seviyesi hariç ÇY ve İY seviyelerine doğru gelişim gösterebilmelerini sağlamıştır. Bu genel sonuçlar doğrultusunda bu bölümde çalışma kapsamında elde edilen bulgular ele alınan her bir araştırma sorusu bağlamında tartışılacaktır.

Fonksiyonun belirsizlik durumunda limit bulma ile ilgili bu çalışmada ele alınan sorular kapsamında elde edilen veriler incelendiğinde genel olarak öğrenci cevaplarının SOLO taksonomisine göre çalışılan sorunun tek bir yönüne odaklanan TY ve birleştirici unsur kullanılmayan kopuk bilgi parçaları içeren cevapların yer aldığı ÇY seviyelerine karşılık geldiği görülmektedir. Belirsizlik durumlarına ulaşmada kavramsal anlamaya yakın olmayan bu cevaplar beklenen öğrenmenin gerçekleşmediğini göstermektedir. Derive yazılımı yardımıyla verilen fonksiyonu tanımlamakta, limit bulmakta güçlük çekmeyen MYO öğrencileri, limit aranan noktaları yerine yazmakta ve elde edilen belirsizliği tanımlamakta zorlanmıştır. Ayrıca sonsuzluk ifadesi ile karşılaşan MYO öğrencilerinin sorulara ezbere cevaplar verdiği görülmüştür. Bu ve benzeri cevaplar MYO öğrencilerinin birbiri ile ilişkili olmayan ezbere bilgi parçalarına sahip olduğunu ortaya koymuştur.

Fonksiyonun belirsizlik durumlarında limit değerini bulabilme ile ilgili öğrenmenin gerçekleşmesi için MYO öğrenci cevaplarının birbiri ile ilişkili kavramsal anlamanın olduğu IYY seviyesinde olması gerektiği düşünüldügünde beklenen öğrenmenin gerçekleşmediği açıktır. Soru grupları dağılımına göre incelendiğinde MYO öğrencilerinin en çok zorlandıkları soruların bu grupta olduğu ortaya çıkmıştır. Bunun sebebi limit-süreklilik konusu ve belirsizliklerle ilgili eksiklerin yanı sıra MYO öğrencilerindeki bilimsel bilgi, sonsuz kavramı, fonksiyon kavramı, reel sayı kavramı eksiklikleri olarak gösterilebilir. Belirsizlik durumlarını, limit öğretimini, limit bulmayı ve limit-sürekliliğin zorluğunu inceleyen araştırmaların bazılarında (Çetin, 2009) öğrencilerin sonsuzluğu belirli (genellikle çok büyük) bir sayıya eş tuttuğu veya bir sayı olarak algıladığı, her matematiksel işlemin sayısal bir sonucu olması gerektiği şeklindeki inançları doğrultusunda limit kavramı ile ilişkili belirsizliklerde sıfıra bölme, sıfırın sıfıra bölümü ve sonsuzda limit hesaplamalarındaki başarısızlıkları öğrencilerin eksikleri olarak tespit edilmiştir. Bu 
doğrultuda bu çalışmada elde edilen MYO öğrencilerinin sonsuzu bir sayı gibi algılamaları, tanımsızlı̆̆ı ve belirsizliği anlamlandıramamaları, sonsuzda ve belirsizlik durumlarında limit hesaplamalarındaki başarısızlıkları gibi eksikler bu araştırmaların sonuçları ile paralellik göstermektedir.

Araştırmacı öğretmenin aldığı notlardan, MYO öğrencilerinin belirsizlik durumlarında limit bulmaya yönelik verdiği cevapların öğrenme için yeterli olmasa bile çalışmalar ilerledikçe öğrenme çıtılarının geliştiği ve ifadelerinin teknoloji eğilimli olduğu çıkarımına ulaşılabilir. Teknoloji destekli matematik eğitimi literatüründe yer alan araştırmalar belirsizlik durumları ve limit kavramı gibi öğrencilerin anlamada zorlandığı karmaşık konuların öğretiminde görsel temsiller etkili olurken geleneksel öğretim yöntemlerinin etkisinin daha kısıtlı olduğu belirtilmekte olup (Baki \& Çekmez, 2012; Sevimli \& Delice; 2015) çalışmanın bulgularıyla paralellik göstermektedir. Araştırmacı öğretmen görsel öğelerin kullanılmadığı ortamların öğrencileri ezbere sevk ettiğine ulaşmıştır. Böylece araştırmacı öğretmene göre yükseköğretim matematiğine temel oluşturan limit konusunun görsel ve kavramsal ilişkilerle öğrencilere sunulması önemlidir. Özellikle MYO öğrencilerinin lise eğitimleri boyunca aldıkları yetersiz ve ezbere dayalı matematik bilgisi için bu durum önem taşımaktadır. Bu durum, Biber ve Argün'ün (2015) matematiksel kavram bilgileri sağlam olmadan yükseköğretime başlayan öğrencilerin matematik bilgilerinin yetersiz olduğu sonucu; Sıvacı'nın (2003) matematik başarısının mezun olunan lise türüne göre farklılaştı̆̆ı sonucu ile tutarlılık göstermiştir. Yine de öğrenci cevaplarının TY seviyesinden, ÇY seviyesine gelişimi ve görselleri tercih etmesi teknolojinin süreçteki destekli oluşum rolünü açığa çıkarmaktadır.

Fonksiyonun grafiğini inceleyip sürekli olduğu aralıkları bulabilme ile ilgili MYO öğrenci cevaplarının SOLO taksonomisine göre ÇY ve gelişim göstererek IYY seviyesinde çıktığ görülmektedir. Bu durum Derive yazılımı üzerinde grafik çiziminde sorun yaşamayan MYO öğrencilerinin fonksiyonların grafiğini inceleyip sürekli olduğu aralıkları bulmada ve grafik üzerinde verilen noktadaki limiti incelemede beklenen öğrenmeye yaklaştığını göstermektedir. Grafik üzerinde $\infty^{\prime}$ a nasıl yaklaşabilecekleri hakkında fikir yürütmede zorlanan MYO öğrencilerinin sürekliliği incelerken sıfır noktasına odaklandığı, buradaki limiti merak ettiği ve sıfırdaki yoğunlaşmayı kalp atışına benzettiği görülmektedir. Grafiğin sıfır noktasında dikkat çekici olması öğrencilerin grafiği inceleme isteğini arttırmıştır. Yazılımda bu nokta için limiti sıfır bulan öğrencilerin grafik ile ilgili yorumları TY ve ÇY 
seviyesinden İY seviyesine doğru gelişim gösterdiği görülmüştür. Bazı öğrencilerin yazılım üzerinde grafik çizimi yaptıktan sonra fonksiyonun $\infty$ 'a yaklaşırken alacak olduğu limit değerinin grafiğini çizip, fonksiyon grafiğinin sonsuza doğru limit grafiğine yaklaşıp yaklaşmadığını incelemek istemesi öğrencilerin anlık değişimi görsel olarak incelediklerinin göstergesi olarak bu cevapların ÇY ve İY seviyesinde yorumlanmasında etkili olmuştur. Özellikle birçok matematik konusunda zorlanan MYO öğrencileri için BDÖ ortamında (fonksiyonların grafikleri ve bu grafikler üzerinde hareket edip anlık değişimden faydalanarak) limit-sürekliliğin öğrenilmesi geleneksel öğretim yöntemine nazaran daha etkili olduğu görülmüştür. Böylece öğrencilerin beklenen öğrenmeye yaklaşabilmesi görsel temsilleri kullanmalarındaki gelişimin etkisi olarak gösterilebilir. İlgili literatürde (Dubinsky, Cottrill, Nichols, Schwingendorf, Thomas \& Vidakovic, 1996; Hoyles \& Noss, 1999; Porizo, 1994) grafik üzerinde hareket edebilme gibi görsel temsillerin öğrenmeye olumlu etkilerine değinmişlerdir. Bu doğrultuda bu çalışmaların sonuçları ile çalışmada görsel temsillerin kullanımı ile ilgili yukarıda belirtilen olumlu sonuçlar paralellik göstermektedir.

Monaghan, Sun ve Tall (1994) BCS'den Derive programı kullanımı sonucu öğrencilerin limit kavramı ile ilgili “yakınsama” ve "sonsuzluk" algılarını göz ardı ettiğini ve öğrencilerin sadece çözüme odaklandığını belirtmişlerdi. Buna karşın bu çalışmada sadece çözüme odaklanan MYO öğrenci cevaplarının çalışma ilerledikçe özellikle Derive yazılımında grafik üzerinde limit-süreklilik inceleme ile ilgili yapılan çalışmaların öğrencilerin "yakınsama" ve "sonsuzluk" algılarını öğrenmeleri üzerinde etkili olduğu sonucuna ulaşılmıştır. Ayrıca öğrencilerin grafik üzerinde hareket edip süreksizlik noktalarına ulaşarak yakınsamayı, grafiği küçültüp-büyüterek sonsuza doğru uzanan kolları inceleyerek ise sonsuzluğu anlamlandırdıkları görülmüştür. Monaghan, Sun ve Tall'ın (1994) değerlendirmesi dikkate alındığında yazılımın cebirsel kısmından ziyade anlık değişimlerin incelenebildiği grafik kullanımının öğrenmede daha etkili olduğu söylenebilir. Ayrıca MYO öğrencilerinin yazılım üzerinde çizdikleri her bir grafiği günlük yaşamda karşılaştıkları “kaydırak, kalp atışı” gibi somut şekillerle ilişkilendirmesi, öğrencilerin soyut düşünme becerilerini geliştirerek süreklilik aralıklarını bulmalarında ve bu aralıkları limit-süreklilik bağlamında incelemelerinde etkili olmuştur. Böylece araştırmacı öğretmene göre yükseköğretim matematiğine temel oluşturan limit-süreklilik konusunun görsel ve kavramsal ilişkilerle öğrencilere sunulması önemlidir. Sonuç olarak kavramsal anlamanın olduğu İY seviyesinde verilen cevapların bazıları zayıf olsa bile öğrencilerde fonksiyonun 
sürekli olduğu aralıkları grafik üzerinde göstermeyle ilgili öğrenmenin geliştiği açıktır. MYO öğrencilerinin öğrenme sürecinde yazılımda yer alan görsel temsilleri tercih etmesi ve teknolojinin süreçteki desteği bu gelişimin önemli bir göstergesi olarak yorumlanmıştır.

Limit-süreklilik arasında ilişki kurabilme ile ilgili genel olarak MYO öğrenci cevaplarının SOLO taksonomisine göre ÇY ve ÇY+ seviyesinde çıktığ1 görülmüştür. Bu durum limitsüreklilik konusunu ilişkilendirme ile ilgili hedeflenen öğrenme gerçekleşmese bile genel bilgiye yaklaşıldığını göstermektedir.

Fonksiyon için grafik çizme eğiliminde olan ve limit-süreklilikle ilgili ezbere bilgi parçalarından kurtulamayan MYO öğrencilerinin bu gruba ait sorulara cevap verirken önceki çalışmaların etkisinde kaldığı ve bazı kavram yanılgılarına sahip olduğu ortaya çıkmıştır. Bu sonucun ortaya çıkmasında soru gruplarında yer alan fonksiyonların incelenmesi istenen noktalarda tanımsız veya belirsiz olmasının yanı sıra alt yapı olarak MYO öğrencilerinin kural temelli ve ezbere öğrenmeye alışkın olmaları gösterilebilir. İlgili literatürede (Biber \& Argün, 2015; Fernandez, 2004) öğrencilerin limit ve süreklilikle ilgili kavramsal ilişki kurmada ayrıca limit kavramının formal tanımını anlamada zorlandı̆̆ına değinilmiştir. Özellikle görsel öğelerin kullanılmadı̆̆ı geleneksel içerik ve yaklaşımların yer aldığı öğrenme ortamlarında öğrenim gören ve yükseköğretime başlayan MYO öğrencilerinin kural temelli, ezbere düşündüğünü gözlemleyen araştırmacı öğretmenin bu çıkarımı Sevimli ve Delice'nin (2015) teknoloji destekli öğretimin teorik farkındalığı geliştirebileceği sonucuyla paralellik göstermektedir. Araştırmacı öğretmen bu dersi gözlemlediği her dönem MYO öğrencilerinde limit-süreklilik ile ilgili kavram yanılgılarına rastlamıştır. Özellikle öğrencilerin "grafik dışında sürekliliği inceleyememesi”, "sonsuzu limit değeri olarak algılaması”, "belirsizliklerin veya tanımsızlıkların olduğu yerlerde limitin olamayacağı inancı", "tanımsızlık ve belirsizlik kavramlarını birbirinden ayırt edememesi”, "bir noktada birden çok limit değerinin olabileceği düşüncesi" ve "süreklilik için fonksiyonun tanımlı ve limit değerinin fonksiyonun o noktadaki görüntüsüne eşit olması gerekliliğini dikkate almaması" gibi kavram yanılgıları diğer araştırmacılar (Akbulut \& Işık, 2005; Tall \& Vinner, 1981) tarafından tespit edilenlerle oldukça benzerlik göstermektedir. MYO öğrencileriyle çalışmaları süresince benzeri yanılgılara fazlasıyla rastlayan araştırmacı öğretmen bunun sebebini başta MYO öğrencilerinin ezbere dayalı matematik bilgisi olmak üzere, limit-süreklilik konusu, belirsizlikler, bilimsel bilgi, sonsuz kavramı, fonksiyon kavramı, reel sayı kavramı eksiklikleri olarak not almıştır. Araştırmacı öğretmen notlarında 
bu eksikleri gidermede öğrencilerin öğrenmelerini destekleyecek öğrenme ortamlarının oluşturulması gerektiğini vurgulayarak özellikle görsel öğelerin kullanılmadığı ortamlarda öğrencilerin öğrenme güçlüklerini aşamadıklarına yer vermiştir. Teknoloji destekli matematik eğitimi literatüründe öğrencilerin anlamada zorlandığı karmaşık konuların öğretiminde görsel temsillerin etkili olurken geleneksel öğretim yöntemlerinin etkisinin daha kısıtlı olduğunu belirten çalışmalar (Baki \& Çekmez, 2012; Ertem-Akbaş, 2019) araştırmacı öğretmenin notlarındaki bulgularla paralellik göstermektedir. Bu bulgular doğrultusunda MYO öğrencilerinin limit ve sürekliliği ilişkilendirmeyle ilgili verdikleri cevapların beklenen öğrenme düzeyi için yeterli olmadığı görülmüştür. Buna rağmen öğrencilerin limit-süreklilik konusunun başlangıcında konu ile ilgili fikir yürütemezken yazılım üzerinde cebirsel işlemler ve grafik çizimi ile limit olmadan sürekliliğin olmayacağını, süreklilik için grafiği incelemek gerektiğini, grafikte boşluk olunca sürekliliğin olmadığını, fonksiyonun belirsiz ve tanımsız olduğu noktalarında limit-süreklilik inceleme ile ilgili şüpheye düştüklerini belirten ifadeleri, görsel temsillerin öğrencilerin zihinlerinde yeni fikirlerin oluşmasında etkili olduğunu göstermektedir. Bu durum araştırmacı öğretmenin çalışmanın başlangıcında ortaya koyduğu “BCS destekli ortamda MYO öğrencileri zihinlerinde yeni fikirler oluşturup, cevaplarını teknolojiye dayalı olarak verebilir" varsayımını doğrular niteliktedir. Böylece yükseköğretim matematiğine temel oluşturan limit-süreklilik konusunun görsel ve kavramsal ilişkilerle öğrencilere sunulmasının öğrencilerin bu kavramlarla ilgili soyut düşünme becerilerini geliştirmede önemli olduğu düşünülmektedir. Özellikle MYO öğrencilerinin lise yıllarında aldıkları yetersiz ve ezbere dayalı matematik eğitimi için bu durum önem taşımaktadır. Çalışma sürecinde öğrenciler meslek lisesi çıkışlı olduklarını, ortaöğretim matematik derslerinde limit-süreklilik konusunu işlemediklerini, sözel ve eşit ağırlık çıkışlı olduklarını belirtmiştir. Öğrencilerin limit-süreklilik arasında kavramsal ilişki kurabilmede yetersiz kalan TY seviyesindeki ifadeleri lise eğitimleri boyunca aldıkları matematik öğretiminin önemini ortaya çıkarmıştır. Önceki öğrenmelerinde var olan eksiklere rağmen BCS yazılımının kullanıldığı ortamda MYO öğrencilerinin limit-süreklilik arasında ilişki kurabilmeleri ile ilgili öğrenme çıktılarının ÇY seviyesine gelişim gösterdiği görülmüştür.

\section{Öneriler}

Çalışmadan elde edilen sonuçlar, MYO'larda okutulan genel matematiğin soyut bir yapıya sahip olan analiz dersi içerisinde ele alınan kavramların somutlaştırılması ve 
hazırlanan öğrenme-öğretme etkinliklerinin ortaya konuş biçiminin önemi ortaya çıkmaktadır. Bu sebepten kavramsal anlama boyutunun ihmal edildiği düşünülen matematiğin soyut kavramlarını somutlaştırarak daha iyi anlamalar gerçekleştirme adına öğretim süreçlerinde BCS kullanımı önerilmektedir. Ayrıca öğrenci seviyesi dikkate alınarak soyut kavramların öğrenciler için nasıl anlamlı hale getirilebileceği konusunda görsel öğeleri ve sözel iletişimi destekleyen etkinlikler hazırlanabilir.

BCS yazılımlarından biri olan DERIVE, MYO öğrencilerine limit-süreklilik konusu öğretiminde çalışma yapraklarında yer alan fonksiyonlar için cebirsel (sayısal-sembolik) hesaplar yapabilme, fonksiyonların iki-üç boyutlu grafiklerini oluşturma ve grafik üzerinde hareket edebilme gibi olanaklar sunmuştur. Bu olanaklar öğrencilerin limit-süreklilik konusunu teorik ve kavramsal öğrenmelerinde yeterli olmasa da konuyu sezgisel olarak anlamalarına ve yorumlamalarına yardımcı olmuştur. Dolayısıyla limit-süreklilik konusu öğretimi sürecinde bir BCS olan DERIVE yazılımından faydalanılması önerilmektedir. Ayrıca cebirsel işlemler ve grafik üzerinde anlık değişimden faydalanmayı sağlayan DMY kullanımı da önerilebileceği gibi, cebirsel işlemler ile grafiğin aynı ekranda olduğu bir BCS olan LiveMath yazılımı kullanımı da önerilebilir.

Araştırmanın sonuçları ele alınan kazanımlarla ilgili MYO öğrencilerinin öğrenme çıktılarının ders başlangıcında TY hatta YÖ seviyesinde olduğunu göstermiştir. Ders süreci ilerledikçe ve BCS yazılımı etkin kullanıldıkça elde edilen öğrenme çıtılarının ÇY ve ÇY+ seviyesine doğru gelişim gösterdiği ortaya çıkmıştır. Araştırmada ortaya çıkan bu durumun MYO öğrencilerinin ortaöğretim eğitimleri boyunca geleneksel öğretim yöntemleri ile aldıkları yetersiz ve ezbere dayalı matematik bilgisine bağlı olduğu düşünülmektedir. Bu doğrultuda ortaöğretim öğretim programlarında limit-süreklilik kavramlarının öğretimine ve öğretim yöntemlerine ilişkin konuların formel tanımları ve kavramsal anlama boyutu ihmal edilmeden, teknolojinin ve görsel öğelerin kullanımını hedef alan yeniliklerin yapılması önerilmektedir. Oysa son zamanlarda ortaöğretim programında yapılan değişikliklerde bazı belirsizlik durumlarının ve limit-süreklilik konusuna ilişkin bazı konuların çıkarıldığı görülmektedir. Bu durumda çıkarılan bu konularla ilgili öğrencilerde beklenen ön öğrenmelerin olmayacağı açıtır. Dolayısıyla bu duruma bağlı olarak yükseköğretim sistemleri arasında uluslararası ilişkilendirmeyi sağlamak, yükseköğretim sistemlerinin birbirini tanımasını kolaylaştırmak, öğrenenlerin ve mezunların hareketliliğini arttırmak amacıyla Bologna sürecinde ele alınan ders içerikleri ve işleyişleri yeniden ele 
alınıp öğrencilerin ilgili konulara ilişkin formel tanımları ve kavramsal anlamalarını destekleyecek şekilde düzenlenmesi önerilebilir.

Araştırmada her ne kadar BCS destekli öğrenme ortamının etkisi dolaylı olarak ele alınsa da Derive yazılımı gibi bilgi teknolojilerinin matematik eğitime entegrasyonu ile ezbere bilginin ortadan kalkacağı ve öğrencilerin soyut düşünme becerilerinin gelişeceği düşüncesinden hareketle MYO'larda ele alınan genel matematiğin soyut kavramlarının öğretimine ilişkin hazırlanacak öğrenme ortamlarında uygun konu eşliğinde uygun yazılım kullanımını konu alan bir araştırma gerçekleştirilebilir. Bu çalışmada dersi yürüten araştırmacı, geleneksel ders anlatımı sürecinde karşılaştığı soruna çözüm üretmek, öğretimin niteliğini arttırmak ve geliştirmek amacıyla araştırmacı öğretmen (eylem araştırması) yöntemini kullanmıştır. Yapılacak benzer çalışmalarda MYO öğrencilerinin limit-süreklilik konusunu öğrenmeleri, tasarlanacak olan başka bir öğrenme ortamı ile geleneksel öğrenme ortamında (deney-kontrol gruplu) kıyaslanarak deneysel tasarımın benimsendiği bir çalışma yürütülebilir.

Yapılan bu çalışmada veri analizi SOLO taksonomisine dayalı olarak yapılmıştır. SOLO taksonomisi MYO öğrencilerinin limit-süreklilik konusundaki öğrenme çıktılarını değerlendirme açısından elverişli bir yöntem sunmuştur. Bu açıdan öğrenme sürecini değerlendirmeye yönelik çalışma yapmak isteyenler için önerilebilir.

\section{Bilgilendirme}

$\mathrm{Bu}$ çalışma birinci yazar tarafından ikinci yazarın danışmanlığında tamamlanan doktora tezinden üretilmiştir.

Bu çalışmada kullanılan verilerin 2020 yılı öncesine ait olduğu araştırmacılar tarafından onaylanmıştır.

Yazar Katkı Beyanı

Elif ERTEM AKBAŞ: Kavramsallaştırma, veri toplama, metodoloji, ön taslak yazımı, inceleme-yazma ve düzenleme

Adnan BAKI: Kavramsallaştırma, metodoloji, danışmanlık ve denetim (ölçme aracı, veri analizi), inceleme-yazma ve düzenleme 


\section{Kaynaklar}

Akbulut, K., \& Işık, A. (2005). Limit kavramının anlaşılmasında etkileşimli öğretim stratejisinin etkinliğinin incelenmesi ve bu süreçte karşılaşılan kavram yanılgıları. Kastamonu Ĕ̈itim Dergisi, 13(2), 497-512.

Baki, A. (2001). Bilişim teknolojisi 1şığı altında matematik eğitiminin değerlendirilmesi. Milli Ĕgitim Dergisi, 149(91), 26-31.

Baki, A. (2008). Kuramdan uygulamaya matematik eğitimi (Genişletilmiş 4.baskı). Ankara: Derya Kitabevi.

Baki, M., \& Çekmez, E. (2012). İlköğretim matematik öğretmeni adaylarının limit kavramının formal tanımına yönelik anlamalarının incelenmesi. Turkish Journal of Computer and Mathematics Education, 3(2), 81-98.

Biber, A. Ç., \& Argün, Z. (2015). The relations between concept knowledge related to the limits concepts in one and two variables functions of mathematics teachers candidates. Bartm University Journal of Faculty of Education, 4(2), 501-515.

Biggs, J. B., \& Collis, K. F. (1991). Multimodal learning and the quality of intelligent behaviour. In H. Rowe (Ed.), Intelligence: Reconceptualization and measurement (pp. 5776). New Jersey: Laurence Erlbaum Assoc.

Biggs, J. B., \& Collis, K. F. (2014). Evaluation the quality of learning: the SOLO taxonomy (structure of the observed learning outcome). New Jersey: Academic Press.

Castro, C. H. (2011). Assesing the impact of computer programming in understandinglimits and derivatives in a secondary mathematics classroom. (Unpublished doctoral dissertation). Georgia State University, Atlanta.

Chang, Y. K., \& Li, W. T. (2005). Existence results for second order impulsive functional differential inclusions. Journal of Mathematical Analysis and Applications, 301(2), 477-490.

Cornu, B. (1991). Limits. In D. Tall (Ed.), Advanced mathematical thinking (pp. 153-166). Dordrecht/Boston/London: Kluwer Academic Publishers.

Çavuş, H., \& Eskitaşçıŏlu, E. İ. (2016). Türkiye'de matematik öğretiminde öğretmenlerin eğitim ortamlarında bilgisayar ve matematik programlarından yararlanma ölçütleri. Kırşehir Ĕ̆itim Fakültesi Dergisi (KEFAD), 17(3), 457-475.

Çelik, D. (2007). Öğretmen adaylarının cebirsel düşünme becerilerinin analitik incelenmesi. (Yayınlanmamış doktora tezi). Karadeniz Teknik Üniversitesi, Trabzon.

Çetin, İ. (2009). Students' understanding of limit concept: An APOS perspective. (Doktoral dissertation). Middle East Technical University, Ankara.

Dubinsky, E., Cottrill, J., Nichols, D., Schwingendorf, K., Thomas, K., \& Vidakovic, D. (1996). Understanding the limit concept: Beginning with a coordinated process schema. The Journal of Mathematical Behavior, 15(2), 167-192.

Ertem-Akbaş, E. (2016). Meslek yüksekokulu öğrencilerinin bilgisayar destekli ortamda "limitsüreklilik" konusundaki öğrenmelerinin solo taksonomisine göre değerlendirilmesi (Yayınlanmamış doktora tezi). Karadeniz Teknik Üniversitesi, Eğitim Bilimleri Enstitüsü, Trabzon.

Ertem-Akbaş, E. (2019). The impact of EBA (Educational Informatics Network) assisted mathematics teaching in 5th grade fractions on students' achievements. Journal of Computer and Education Research, 7(13), 120-145.

Fernández, E. (2004). The students' take on the epsilon-delta definition of a limit. Problems, Resources, and Issues in Mathematics Undergraduate Studies, 14(1), 43-54.

Hoyles, C., \& Noss, R. (1999). Dynamic geometry environments: What's the point? Mathematics Teacher, 87(9), 716-717. 
Johnson, A. P. (2005). A short guide to action research (2nd edition). Boston: Pearson Education. Jones, G. A., Thornton, C. A., Langrall, C. W., Mooney, E. S., Perry, B., \& Putt, I. J. (2000). A framework for characterizing children's statistical thinking. Mathematical Thinking and Learning, 2(4), 269-307.

Karadeniz, M. H., \& Kelleci, D. (2015). Meslek yüksekokulu öğrencilerinin matematik dersine ilişkin tutumlarının başarıya etkisi. Karadeniz Sosyal Bilimler Dergisi, 7(14), 1-16.

Kokol-Voljc, V. (2000). Examination questions when using CAS for school mathematics teaching. The International Journal of Computer Algebra in Mathematics Education, 7(1), 6375.

Lincoln, Y. S., Lynham, S. A., \& Guba, E. G. (2011). Paradigmatic controversies, contradictions, and emerging confluences, revisited. The Sage Handbook of Qualitative Research, 4, 97-128.

Miles, M. B., \& Huberman, A. M. (1994). Qualitative data analysis: An expanded sourcebook. London: Sage Pub.

Mills, G. E. (2003). Action research a guide for the teacher researcher. (2nd. edition), New Jersey: Pearson Education.

Monaghan, J., Sun, S., \& Tall, D. O. (1994). Construction of the limit concept with a computer algebra system. Psychology of Mathematics Education,18, 279-286.

Papert, S. (1993). The children's machine: Rethinking school in the age of the computer. New York, USA: Basic Books, Inc.

Pegg, J., \& Tall, D. (2005). The fundamental cycle of concept construction underlying various theoretical frameworks. International Reviews on Mathematical Education, 37(6), 468-475.

Philips, K. D., \& Carr, K. (2009). Dilemmas of trustworthiness in preservice teacher action research. Action Research, 7(2), 207-226.

Sevimli, E., \& Delice, A. (2015). Can technology-assisted instruction improve theoretical awareness? The case of fundamental theorem of calculus. Turkish Journal of Computer and Mathematics Education, 6(1), 68-92.

Sıvacı, S. Y. (2003). Sını öğretmenliği son sını öğrencilerinin matematik alan ve meslek bilgisi yeterlilikleri ile derse yönelik tutumları. (Yayınlanmamış doktora tezi). Hacettepe Üniversitesi, Ankara.

Strauss, A. L. (1987). Qualitative analysis for social scientists. Cambridge: Cambridge Uni. Press.

Tall,D., \&Vinner, S.(1981).Concept image and concept definition in mathematics with particu lar reference to limits and continuity. Educational Studies in Mathematics,12,151-169.

Yıldırım, A., \& Şimşek, H. (2013). Sosyal bilimlerde nitel araştırma yöntemleri. (Genişletilmiş 9. Baskı). Ankara: Seçkin Yayıncılık.

Yılmaz, G. K., Ertem, E., \& Güven, B. (2013). Dinamik geometri yazılımı cabri'nin 11. sınıf öğrencilerinin trigonometri konusundaki öğrenmelerine etkisi. Turkish Journal of Computer and Mathematics Education, 1(2), 200-216.

Zengin, Y. (2017). Komşuluk ve yığılma noktası kavramlarının dinamik matematik ortamında keşfedilmesi üzerine bir araştırma. Mehmet Akif Ersoy Üniversitesi Eğitim Fakültesi Dergisi, 43, 302-333. 